Dokuz, Eylül Üniversitesi

İlahiyat Fakeiltesi Dergisi

2014/1, Sayı 39, ss. 25-52.



\title{
1175 İSPANYOLLARIN CEZÂYIIR SALDIRISI HAKKINDA RİSALE (HOCA MUSTAFA ŞEMSİ)
}

Ahmet GEDIK*

\section{ÖZET}

Bu makalede, Hoca Mustafa Şemsi'nin 1175/1761 yılındaki Cezâyir'e yapılan İspanyol saldırısı ile ilgili yazdığı Osmanlı Türkçesi ile kaleme alınan risâle transkribe edilmiş ve müellifin hayatı hakkında bilgiler verilmiştir. Risâlede, Cezâyir'i ele geçirmenin bütün Afrika'yı fethetmek anlamına geldiğini çok iyi bilen İspanya'nın olanca gücüyle saldırdığı bir dönemde, Osmanlı Türkleri'nin ve Cezâyirlilerin direnişi destansı bir şekilde anlatılmıştır. Osmanlı ve İspanyol güçleri arasındaki mücâdele anlatılırken âyet ve hadislere yer verilmiş olması dikkat çekicidir. Risâle, süslü bir anlatım tarzına sahiptir. Anahtar Kelimeler: Kuzey Afrika, Hoca Mustafa Şemsi, Osmanlı Türkleri, Cezâyir.

\section{THE RISALE ON SPANISH ATTACK TO ALGERIA IN 1175 \\ (KHOJA MUSTAFA SHAMSI)}

\section{ABSTRACT}

In this article, we have transcribed Khoja Mustafa Shamsi's book that he wrote with Ottoman Turkish about the Spanish attack to Algiers in 1175/1761, and have given information about author's life. In this book, the Ottoman Turks and Algerians' resistance are described in the epic way when Spain attacked Algeria. Spain knew very well that seizing Algeria meant to conquer of whole Africa. Interestingly, Qur'ânic verses and hadiths are mentioned to explain tussle between the Ottoman and Spanish forces. The book that we have examined has a fancyway of expression.

Keywords: North Africa, Khoja Mustafa Shamsi, Ottaman Turkish, Algeria

\section{GİRİş}

\section{HOCA MUSTAFA ŞEMSİ el-İSTANBULÎ (1229/1813'de sağ)}

Cezâyir Tersanesi reisi olduğunu öğrendiğimiz Hoca Mustafa Şemsi’nin hayatı hakkında pek fazla bir bilgiye sahip değiliz. Çeşme'de Osmanlı donanmasının ağır yara alması üzerine, askerî alandaki sslahatlara hız verilmesi amaciyla memur tayin edilen Baron de Tott'un kurdurduğu "hendese odası" adıyla açılan ilk dershanenin hocası olarak mühendishane talebelerinden Molla Mustafa Şemsi bu göreve getirilmiştir. Fransa'dan, gemi inşaasına nezâret edip yeni teknikleri öğretmesi amaciyla getirilen Baron de Tott'un (ö.1793) yanında göreve başlamıştır. Birkaç yıl çalıştıktan sonra kazandığı çeşitli tecrübeleri

* Yrd. Doç. Dr., İzmir Katip Çelebi Üniversitesi İslami İlimler Fakültesi Öğretim Üyesi 
neticesinde Kalas iskelesinde inşâ edilecek firkateynin nezaretine memur edilmiştir. Daha sonra ise 1229/1813 yilında Antalya bölgesinde kaptanlık ile görevlendirilmiştir. ${ }^{1}$

Hoca Mustafa Şemsi'nin hayatı ile ilgili az da olsa önemli bilgileri bulabildiğimiz IRCICA tarafindan hazırlanan "Osmanlı Askerlik Literatürü Tarihi" adlı iki ciltlik eserde müellifin "Barud Hakları Hakkında Türkçe Bir Risâle ve Barud Hakları Cedveli" adlı bir eserinden bahsedilmektedir. Konumuzu teșkil eden ve İSAM'ın Osmanlıca Risaleler Veri Tabanında bulunan "1175 İspanyolların Cezayir Saldırısı Hakkında Risale" de aynı müellifindir.

\section{RISSALE VE MUHTEVASI}

Elimizdeki risale, İSAM Kütüphanesi'nde E 13960 no'lu yazma olarak kayıtlıdır. Müellifimiz Hoca Mustafa Şemsi'nin belirttiğine göre bu risale; Hicrî 1189 (1775) yılı, Cemâziye'l Evvel ayının 5. Günü ( 4 Temmuz 1775) Cezâyir topraklarını ele geçirmek üzere yapılan İspanyol saldırısını ve Osmanlı Türkleri’nin müdafaasını anlatmaktadır. Bu sebeple eser, XVIII. yüzyıl sonlarındaki İspanyollar ile Osmanlı Türkleri arasındaki Kuzey Afrika'yı ele geçirme mücadeleleri için önemli bir kaynak niteliği taşımaktadır.

Risale İSAM'da Osmanlıca Risaleler Veri Tabanı içerisinde "1175 İspanyolların Cezayir Saldırısı Hakkında Risale" adı altında kayıtlıdır. Hoca Mustafa Şemsi'nin bu eseri Hicrî 1175 yllındaki İspanyol saldırısı esas alınarak kaydedilmiş olsa da metin içerisinde Hicrî 1189 senesindeki İspanyol saldırısından bahsedilmektedir. ${ }^{2}$ Görüleceği üzere müellifin bu eseri İSAM Osmanlıca Risaleler Veri Tabanı'na "1189 İspanyolların Cezayir Saldırısı Hakkinda Risale” olarak kaydedilmeliydi.

Transkribe ettiğimiz bu risalenin Osmanlı Türkçesi'yle yazılmış asıl metninin sayfa numaralarını çalısmamız içerisinde belirttik. Risale ile ilgili bir

1 Ekmeleddin İhsanoğlu-Ramazan Șeșen, Osmanl Askerlik Literatürü Taribi, c. I, Editiör: Ekmeleddin İhsanoğlu, IRCICA, İstanbul 2004, s. 50. Ayrıca Osmanl tersanelerindeki 1slahat hareketleri ve Hoca Mustafa'nın yerine getirdiği görevlerle ilgili olarak daha geniş bilgi için bkz.: Nurcan Yazıc1, “Osmanlı Devleti'nde Tersane-i Amire Mimarlığı ve Mimarları” Editör: Özlem Kumrular, Türkler ve Deniz, İstanbul 2007, ss. 381-395.

2 ISAM tarafindan risaleye isim olarak verilen H. 1175/M. 1761 yılında Cezâyir'e herhangi bir İspanyol saldırısı olmamıştır. Eser içerisinde geçen 5 Cemâziyel Evvel 1189/4 Temmuz 1775 yılında ise tarihî kaynaklar saldırıdan bahsetmektedir. Geniş bilgi için bkz.: Aziz Semih İlter, Şimâli Afrikada Türkler, c. II, İstanbul 1937, s. 69 ve Mehmet Akif Erdoğru, "XVIII. Yüzyıl Sonlarında Cezâyir'de Türk-İspanyol İlişkileri Bakımından Önemli Bir Türkçe El Yazması: Tarih Al-Mübarek veya Tibr Al-Masbûk Fi Beyânı Cihâd-1 Gâziyân-1 Cezâyir ve Al-Mülûk”, 38. ICANAS (Uluslararası Asya ve Kuzey Afrika Çalışmaları Kongresi), Ankara 2007, ss. 1279-1286. 
atıfta bulunulduğunda verilen sayfa numarası orijinal metindeki sayfa numarasıdır. Transkribe edilen metin içerisinde verilen rakam, asıl metnin sayfa numarasina işaret eder.

Hoca Mustafa Şemsi'nin İstanbul'da almış olduğu eğitimden dolayı sahip olduğu askerî mühendislik bilgisini transkribe ettiğimiz bu risalesinde rahatlıkla görebiliriz. ${ }^{3}$ Müellif, İspanyol donanması ve onların karşısında büyük bir gayretle Cezâyir Şehri'ni savunan Osmanlı Türkleri ve yerel kuvvetlerden oluşan Cezâyir birliklerinin sahip olduğu askeri gücü tüm ayrıntılarıly risalede ortaya koymaktadır. İki ordunun ateşli silahları ve barut gücü özellikle müellif tarafindan belirtilmektedir.4

Cezâyir hâkimiyeti için İspanyol askerleri ile Osmanlı Türkleri ve yerli halktan oluşan savunma gücü arasında deniz savaşı ve devamındaki kara savaşı ayrıntılarıyla anlatılmıştır. Harraş Nehri'nin denize döküldüğü yer olan, Cezâyir Şehri'ne çok yakın bir kumsala çıkarma yapan İspanyol donanması burada tutunmaya çalışmıştır ${ }^{5}$. Cezâyir dayıs $1^{6}$ Mehmed'in $^{7}$ savunma tedbirleri sayesinde kıyıda tutunması İspanyollar için son derece zor olmuştur. ${ }^{8}$

Risale belli bölümlere ayrılmış değildir. Buna rağmen biz metni 3 bölüm halinde inceleyebiliriz. Kırk iki sayfalık metnin giriş bölümü olarak da nitelendirebileceğimiz ilk dört sayfasında İspanyol donanmasının savaş gücü ve Mehmed dayının, tersane kethüdası Seyyid Hasan'ın' savunma tedbirleri yer almaktadır. Gelişme bölümü olan otuz üçüncü sayfaya kadar olan kısımda (532) ise iki ordu arasındaki mücadele, İspanyolların kıyıya çıkarma yapması ayrıntılı bir şekilde anlatılmıştır. ${ }^{10}$ Sonuç bölümü olarak da

3 Bkz. Risale, s. 2, 5, 20, 28.

4 Bkz. Risale, s. 2.

5 Bkz. Risale, s. 4.

6 Dayı, Osmanlı döneminde 1671-1830 yılları arasında çoğunlukla askerî komutanlar arasından seçilerek göreve getirilen Cezayir Eyaleti, Trablusgarp Eyaleti ve Tunus Eyaleti yöneticilerinin unvanıdır. Daha geniş bilgi için bkz. Mehmet Maksudoğlu, "Dayı", DIA , c. IX, İstanbul 1994, ss. 59-60.

7 Cezâyir dayılarından olup uzun süre (1766-1791 ) görevde bulunmuştur. Tedbirli ve disiplinli olmasıyla tanınan bu dayı İspanyol saldırılarının bertaraf edilip 1785 yllında İspanyolları ağır şartlarla barış yapmaya mecbur bırakmıştır. Daha geniş bilgi için bkz.: İlter, age, s. 53.

8 Bkz. Risale, s. 36.

9 Osmanlı Devleti’nde denizcilik ve donanmayla ilgili ilk eğitim kurumu olma özelliği gösteren "hendesehâne"nin ilk hocasıdır. Daha geniş bilgi için bkz.: Nurcan Yazıcı, "Osmanlı Devleti’nde Tersane-i Amire Mimarlığ1 ve Mimarları" Editör: Özlem Kumrular, Türkler ve Deniz, İstanbul 2007, ss. 381-395.

10 İspanyol askerleriyle yapilan çetin mücadele anlatılırken Kur’ân-i Kerîm ayetlerinden yararlanılmıştır. Risale, s. 7 (Bakara Sûresi, 2/89), Risale, s. 9 (Bakara Sûresi, 2/286), Risale, s. 13 (Bakara Sûresi 2/269), Risale, s. 22 (Lokman Sûresi, 31/22), Risale, s. 24 (Saff Sûresi 61/13), risale s. 33 (Mülk Sûresi 67/1). 
değerlendirebileceğimiz son on sayfada (33-42) başarılı bir savunma sonucunda İspanyol donanmasının çıkarma yaptığı sahile tutunamayıp gemilerle kaçmalanı ve arkalarında bıraktıkları yüklü miktarda mühimmat ve silahlardan bahsedilmiştir. ${ }^{11}$ Bir de bu bölüm içerisinde Cezâyir dayısı Mehmed'in İspanyollara karşı zafer kazanan ordusunu teşvik için para dağıtmasının belirtilmiş olması dikkat çekicidir.

Metin içerisinde ismi geçenlerden biri de Konstantin beyi Salih'tir. ${ }^{12}$ Sâlih, Cezâyir Şehri'nin hemen doğusunda bulunan Harraş Nehri'nin denize döküldüğü kumsala ordusuyla birlikte gelerek, İspanyollarla çetin bir mücadeleye girişmiştir. Aslen İzmirli olan Salih, yeniçeri olup Konstantin'e gidip kısa sürede önemli görevlere yükselmiştir. ${ }^{13}$

Müellif sıklıkla Cezâyir'deki Osmanlı askerî gücünü Türklerle birlikte yerli Arapların ve kabâilin ${ }^{14}$ oluşturduğunu belirtmektedir. Kanaatimizce bu durum bölgedeki Türk nüfusunun XVIII. yüzyılın sonlarına doğru hızla azalmasıyla ilgilidir. XVII. yüzyıldaki devlet politikasıyla Anadolu'dan gelen sürekli göç ile birlikte artan Türk nüfusu, bir yüzyll sonra çok azalmıștır. Ganimet gelirlerinin azalması ve bölgeye gidenlere uygulanan imtiyazların kaldırılması, Cezâyir'deki Türk nüfusunu hızla azaltmışır. Ordu, kendisi için gerekli askerî gücü toplumun her kesiminden sağlamaya çalışıyordu. ${ }^{15}$

Dikkatimizi çeken bir husus da, müellifin İspanyol donanmasının ve Osmanlı ordusunun ateş gücünden söz ederken ayrıntılara çok dikkat etmesidir. ${ }^{16}$ Barut ile ilgili çok teknik bilgilere yer verirken ${ }^{17}$, ateşlenen düşman toplarını, çıkan alev ve dumanı yedi başlı ejderhaya benzetmesi son derece ilginçtir.

Hoca Mustafa, Cezâyir dayısı Mehmed'in İspanyollara karşı kahramanca mücadele eden askerlere bolca ihsanda bulunup onların gayretlerini arttırmasından bahsetmektedir. ${ }^{18}$ Komutanlarının gayrete getirdiği Osmanlı ordusunun, tekbirler ve salâvatlarla ${ }^{19}$ düşmana saldırmasından ve düşman

11 Bkz. Risale, s. 36, 38.

12 Bkz. Risale, s. 5.

13 Daha geniş bilgi için bkz.: İlter, age, s. 69.

14 Berberî kabilelerine verilen isimdir. Daha geniş bilgi için bkz.: Fuad Carım, Cezâyir'de Türkler, İstanbul 1962, s. 6.

15 İlter, age, ss. 53-65.

16 Bkz. Risale, s. 16

17 Bkz. Risale, s. 5.

18 Bkz. Risale, s. 29.

19 Bkz. Risale, s. 17, 18. 
cesetlerinin çekirge sürüleri gibi her yeri kapladığından söz edilmesi savaşın vehâmetini göstermektedir. ${ }^{20}$

\section{SONUÇ}

Risale, temelde İspanyol askerlerince kuşatılan Cezâyir Şehri’nin Osmanlı askerlerince savunulmasını konu almaktadır. Bu özelliğinden dolayı Kuzey Afrikka'daki Osmanli-İspanyol mücadelesi anlayabilmek açısından önemli bir kaynak niteliğindedir.

Eserin müellifi, Hoca Mustafa Şemsi bizzat bu savaşlara katılmıştır. Sahip olduğu askerî mühendislik bilgilerini savaş sahnelerini tasvir ederken açıça görebilmekteyiz. Osmanlı ve İspanyol askerleri arasındaki çetin mücadeleleri anlatırken teknik terimleri kullandığı gibi, sabrı ve zaferi müjdeleyen ayetleri, müslüman askerlerin tekbirlerini Peygamberimize getirdikleri salavât-1 şerîfeleri de aktararak hoş bir manevî hava oluşturmuştur.

İslâm dininin Cihad ruhu özellikle belirtilmiştir. Hemen belirtelim ki yazarın ifadelerinde de görüldüğü gibi Osmanlı Türkleri arasında Cezâyir toprakları ve Cihad aynı anlama gelmekteydi. Anadolu'dan yiğitler bu topraklara küffâra karşı cihad yapmak için gelmekteydiler. Böyle olduğu için müellif "Dâru'l-Cihad Cezâyir" ifadesi ile bu bölgeden bahsetmiştir.

Gerçekte müellifin amacı Osmanlı padișahı I. Abdülhamit(1774-1789)'in dikkatini Cezâyir'e ve burada İspanyollara karşı verilen mücadeleye çekmektir. Özellikle Anadolu'dan gelecek her türlü yardım buradaki Osmanlı ordusu için önemliydi.

Eserde XVIII. yüzyıl sonlarında bölgedeki idâri yap1 hakkında bilgi bulunduğu gibi, Konstantin gibi çevredeki önemli bir idârî merkez ve onun yöneticisi hakkında da bilgiler ihtivâ etmektedir.

20 Bkz. Risale, s. 23. 


\section{RİSÂLENİN TRANSKRİPSIYYONLU METNİ}

Bismi'llâhi'r-rahmâni'r-rahîm

1/Elhamdü lillâhi Rabbi'l-âlemîn ve's-salâtü ve's-selâmü 'alâ seyyidinâ Muhammedin ve 'âlihî ve sahbihî ve sellim teslîmâ. Küffâr-1 hâksârı hazelehümullâh İspanyol ile dâru'l-cihâd ve mu'ammerehüllâhü Sultan Cezâyir'de olan halâluş ve cenk ve cidâlin keyfiyet-i hâlin min evveli ilâ âhir ifâde olunsa gerektir. Ve âyîne tarâvet pertevi 'âlem-nümây-1 rûşen kılup cihâna münteşir olup sem'i gûş eyleyen mü’minîn ve mü’minât câru'l-cihâd ve mesken-i evliyâ ve's-sâlihîn Sultan Cezâyir'e evkât-1 fîrûzelerinde du'ây-1 hayırlarından ba'îd ve ferâmûş buyurmaları ve du'ây-1 hayır ile yâd eyleyenlerin Hakk-1 zü’lCelâl dü-cihânda mirâvât-1 hayırlarını hâsıl eyleye, âmîn bi-hurmeti seyyidi'lenbiyâi ve'l-murselîn.

İşbu bin yüz seksen dokuz senesinde mâh-1 cumâde'l-ûlânın gurresinde küffâr-1 hâksâr-1 bedbaht şûm İspanyol la în fikr-i şeyâtîn ile ol hadden tekebbürlük geldi kim 'akl-1 menhûsuna tâbi' olup ve mağrûr-1 sıfât-1 iblîs 'aleyhi'l-la'ne kemâl-i terfî bulup öyle tefekkür eyledi ki ben bu 'âlem-i nümâda bir İspanyol kralı olam, Cezâyir benim mukâbelemde bir misl-i nâmûs-1 sağîrdir ve benim pençe-i şikârımdır ki keyfe hargûş ve hem ben Hind ve mâderîn pâdişâhı ve sâhibü’l 2/'askeri iltâc-1 kadîm olam Cezâyir bir palanga olup benim dest-i kahramânımdan ne gûne necât ve tahlîs-i cân bulsa gerektir. Ve benim heybet-i nâmımdan hûceste eylemeyûb leb-i deryâya mukarrab olan vilâyetlerime gelûb mâl ü emvalleri yağma ve gâret idüp ve nice Hiristiyanları esîr idüp belâ-y1 girdâba giriftâr iderler deyüb hil'at-1 tekebbür-i merdûdu lebsin idüp terviye-i Resûlullâh Sallallâhü Te'âlâ 'aleyhi ve sellem dâru'l-cihâd ve makâm-1 evlîyâi ve's-sâlihîn Cezâyir'i ol laîn kaltabân kendûye 'azîm-i ni'met ve ganîmet bildi. Ve lâkin 'akl-1 murdârı irmedi ki tekebbürlük illallâh zü’l-celâli celle şânühû ve 'amme nevâlühû ve lâ ilâhe gayruhû hazretlerinedir, tekebbürlük Hüdâya yaraşur, sen nesl-i âdemîdensin, vücûdun anla ey insan bir katre menîdensin, bu mes'eleyi fehm itmeyûb tekebbür-i şeyâtîn ile kendüyi hâristân-1 belâya giriftâr ideceğin aslâ sandûka-i fikrinde bulmayûb 'akl-1 şeyâtıniyyesi galebe idûb dedi ki; Cezâyir bir zehr-i ef'i teravvuhu olursa ben ânı âteş-i tiryâkım ile mest-i lâ-ya'kll idûb lâne-i meskenlerin harâb ve zemîne yeksân ve kendülerin belâ-y1 dâm-1 gîrdâba giriftâr idûb sağîr ve kebîr cümle esîr ve bend-i zencîr eylemek emr-i mukarrardır deyüb kemâl-i tekebbürlük eyledi. Ve lâkin ol mağrûr la'în bu mes'eleyi 'akl-1 murdârına getirmeyûb gâfil oldı. Bu felek-i gaddâr nîce serkeşânların ve nîce tekebbürlerin dıraht-1 vücûdların zemîne zîr eylemiştir ve nîce lu'ab-1 fârisi meydanları rahşan-1 sercinden çevkân-1 çengâle tâkûb sezengûn eylemişdir. Ol küffâr-1 haksâr bu fîkîrlerin cümlesin kalb-i murdârından istihrâc idüp kemâl-i mertebe var kuvvetin pâzûy-1 nekbetine getürûb dört yüz elli sefâyin mefrûka ile ve 'akla mukarrab olmayan mühimmât 
ile Engürûs keferesi dahî şâh-1 şehân halîfe-i zemîn nasarahullâhû eyyedehû hazretleri ile mu'âreke bu misillü mühimmât tedârîkiyle meydân-1 mu'ârekeye pâ sürmüştür. Yüz yetmiş 'adûv müdâfi-'i $3 /$ humbara misâli derûnunda sağîr humbara remyi eyler yüz otuz 'adedi destîne sarub üzere altışar vukıyye gülle remy eyler göre el-müdâfi' altı yüz bin humbara otuz bin ve kırtâs el-müdâfi' dört yüz bin ve fişenk-i zâbitân üç milyon her milyonu on kerre yüz bin ve humbara ve sâir mühimmât lâ-yu'ad yüz seksen çift ester, yetmiş çifti bunlar top çekmek içûn iki bin altı pûş-i pür-âteş sipâhi ve sekiz yüz yirmi topçu bin sekiz yüz guzâtadır ki humbarai dest-i endahte ider. Ve kırk bin savletât ki 'asâkir-i menhûse-i cengâverleri hazelehümullâhü bu müzevvirlerin cümlesi karada vilâyet ile tard eylemek içûn âmâde-pirâste olunmuştur. Kırk yedi sefâyîn kûh-1 bülend-i eserdir. Yekbir sefâyinin derûnunda sekiz yüz elli küffâr ol küffâr-1 hâksâr donanma-yı menhûsasın bu uslûb-i minvâl üzere ârâsta eyleyûb 'asâkir-i murdarların derûn-1 sefâyinlerine ahz idüp vakte muntazır oldular. Ol küffâr-1 la înin donanma-y1 mağrûku bu hey'et ile ârâsta ve pîrâsta olup dâru'l-cihâd Cezâyir'e gelmesi muhakkak izhâr oldukda görelim ki âyîne-i devrân ne sûret gösterir, takdîre muvâfik vire her umûru yezdân, dillerde mezkûr cebel-i entâr nâm belde İngilizden seyr-i sür'at ile dâru'l-cihâd Cezâyir'e Hazret-i Mehmed Paşa ve dâmellâhü 'ömrahû ve devletehû hazretlerine kağıdlar gelûb hakîkat hâli kemâl-i mertebe donanma-yı mağrûk İspanyol la'anallâhü 'ale'l-müşrikîn beyân u 'ayân etmişler bu keyfiyet hâl-i ma'lûm oldukda şehinşâh-1 rû-yi zemîn halledallâhü hilâfetehû ilâ yevmi'l-kıyâm hazretlerinin nazargâhı olan düstûr-1 mükerrem ve nizâm-1 memleket, umûr-1 'iyâd-1 müslimîn ve 'akl ile ma'rûf delâil-i ferâset 'iyâdât ile mevcûd 4/Mehmed Paşa sâhib-i tedbîr ve dâmellâhü devletehû ve's-sa'âdetü ilâ yevmi'l-kiyâm. Hak Te'âla bir kuluna kilınca efser-i 'izzet, çâker olur kapusunda ana her dâim devlet, bir kimseye devlet-i sa'âdet ezeli yâr ola, kifayet idi rûz-u şeb mededkâr ola, lâzımdır ki ol kimesne ki fikr-i tedbîr zî k1ymet ve envâ-' ${ }^{\prime}$ menfa'at ile mu'ammer ola ve re'y-i memleket ve 1slâh-1 ümmet-i Muhammed ola, 'inâyet ve nusret-i Hüdâ ana dâim mưîn olub düşman-1 bed-i fa'alleri üzerine küllü hâl zafer olması mukarrardır. Ümûrîn-i Hakk'a tevekkül eyleyen oldı selîm, 'avn ider ana bilâ-şek kâdir-i hayy-1 halîm, ve meşhûr meseldir: Menfa'atü'r-re'yü tedbîr fâide-i şecâ'atten kesîrdir; er-re'yü kable şecâ'atü'ş-şece'ân; zîrâ ki merd ü bârizi çend ki şecî‘u bahâdır ola. Meydân-1 mukâtelede sekiz ya on ya yirmi, ya otuz ve hamsîn veya mie şahıs ile mukâbeleye kâdir ola. Bundan kesîrine tâkat olması mübâlağa idügi zâhirdir. Ammâ sâhib-i tedbîr bir fikkr-i isâbet-pezîr ile nîce iklîm ve mülk-i 'azîmi zabt u teşhîr ider ve bir re'y-i temâsiyle nîce leşker-girânı perîşân ve nîce kûşûr-1 âbâdât-1 virân ve hâk-ile yeksân ider, küffâr-1 hâksârın donanma-y1 menhûsları içûn Hazret-i Mehmed Paşa meddallâhü 'ömrahû, Hak Te'âlâ virmesün mihr-i cemâline küsûn, tuğyân-1 a'dâya oldur şerefi berk-i süyûf. Sandûka-i fikîrleri mecmû'ası feth idûb fetevâ-yı tedbîr 'alâ külli hâl, levâzım-1 harbe emr-i usluplar1 öyle câri oldu ki vilâyet-i celîlenin cânib-i erba'asında olan gâzî burc ü bârûları kemâl-i kudret ile nizâm-1 kâide üzere ta'mîr ve takayyüd idüp vilâyet 
topçubaşısı işgüzâr olmakla emr-i celîl muktezâsınca yed-i tasarrufunda olan burclara işgüzâr topçular ta'yîn ve mu'în eylediler ve her bir çâkere 'ale'r-rifâ' kadarınca 'asâkîr zafer-i nusret ta'yîn olunub reft-i ser-peykeri 5/ejder mukâbili a'dâ ve sedd-i düşman oldular, ve tersâne kethüdâsı sa'âdetlü mekremetlü Seyyid Hasan ve sâhib-i şecâ‘at gayret-i dîn-i Îslâm-1 kemterîn bend-i meyân idüp ol mübârek huceste-kadem ol rûşen ve ehl-i kerem-i zarîf muktezâsınca yed-i tasarrufunda olan sedd-i düşman ve ülfet sırr-1 sûbân-1 mânendi çâr-kûşe limân burçların kemâl-i nefìziyle ta'mîr ve nizâm-1 tamâm-ile kâr-güzâr adamlar ve topçular ve deryâ kapudânları ve derya adamları ile ta'mîr olunub ve üç bin 'asâkir-i İslâm ile ta'mîr olundu. 'Alâ kaderi't-tâfe rûy-i dahk ile cümlesine mu'âmele olunub 'asâkir-i zaferi'l-mûcâhidîn semi'nâ ve ata'nâ dediler. Derûn-1 burçlarda olan 'asâkir nusret-i şi âr-1 fitâneleri dûşende dostları ateş-zende olub seb'atü'r-rüûs su'bân gibi dem çekerler idi. Allâhü yansuruhüm dilîmân-1 celîlede beste-sefine humbara ve bir sefine-i nârı müheyyâ olundu. Ve cümle İslâm dedîler. Hudâdır nere mu'în, cenk ideriz mezdimiz hûr-1 'în, ba'dehû ol rütbe-i velî Hazret-i Mehmed Paşa devâmallâhü 'ömrahû ve eyyâmuhû şarkan ve garben serîr-i sür'at menziller ve beğlere emr-i şerîfleri irsâl olunub beğler ve 'asâkir zaferallâhü yensuruhüm deyûb emr-i şerîfe sem'an vet'ân deyûb cümle 'asâkir-i zaferu'l-mücâhidîn ve beğler dediler, canımıza gîdâ itdi bu nî‘meti zü'lcelâl, cihâd ile sebîlullâh kalbimiz ferhundekâl, ve mîr-i mükrim Sâlih Beğ te'accel-i itâ'at emr-i seyr-i sür'atle Kostantine'den orduy-1 mansûresin göç idüp dâru'l-cihâd ve makâm-1 evliyâ Cezâyir'e gelûb ve orduy-1 mansûresin nehr-i harrâş nâm mevzi'a nüzûl eylediği Cezâyir'in sülûkudur Cezâyir'e iki sa'at mesâfedir ve mîr-i mükerrem Tatra beği ol dahî kezâlik orduy-1 mansûresin nehr-i humus nâm mevzi'a nüzûl eyledi: Vâki-'i dâhili Temnetiyos Cezâyîr'e üç saat mesâfedir. 6/Ve halîfe Beğ el-ğarbu 'ayni'r-ribât nâm mevzi'a nüzûl eyledi, Cezâyir'e nısf-1 sa'at mesâfedir, Cezâyir'in kıblesidir ve mîr-i hûr-i mükrim orduy-1 mansûresin bâb-1 ölût nâm-1 mevzi'a ki cebel-i yüzyer teb'a tahtına nüzûl eyledi. Mîr-i mîrân paşay-1 'âlişân hazretlerinin kethüdây-1 mekremetleri tûl-i 'ömruhüm orduy-1 mansûrelerin Haşmâ nâm mevzi'a nüzûl eyledi, Allâhü yansuruhûm Cezâyir'in kıblesidir bir sa'atlik mesâfedir, ve ağây-1 mûkerrem, Allâhû zîde nusretehüm. Orduy-1 mansûresin Hûnes nâm mevzía nüzûl eyledi, mezkûr altı orduy-1 mansûreler 'asâkir-i zafer-i nusret ile ta'mîr olub serdengeçdi ağaları ve dâü'l-kılıç ağaları sancakdarları ve 'asâkir-i nusret-şi'ârryla muktezâ-y1 emri mûcibince ta'yîn ve mu'ayyen olunub herkes olduğu makâmın iktizâ-yı hâline göre hizmetlerine mukîm olunub yerli yerine vaz' olunub muktezâ-y1 tardi ve levâzım-1 harbi yerine getürub tedbirlerinde bir kusûr komayub cihandârllğın hil'atın lebs idüp ve 'akl u hikmette Hak celle ve 'ale'ş-şâna 'amme nevâle hazretleri tevfiz-i refík idüp hazîne fikkrinde bir şeyi noksan görmeyüb her umûr-1 levâzîmesin kemâl-i mertebe ile müheyyâ ve ârâ-beste kılmıştır. Elhamdü lillâhi hamden kesîran 'alâ 'aklihî, bu misillü vezîr-i zîsân 'akl u dermeyân fikr-i zî-kiymet ve tedbîr-i bî-nazîr her mâder doğurmamışır. Ve subh-1 
sa'âdeti âfâk-1 kerâmetten cülû' eylemiştir. Bâreke 'ömrahû, kerâmet gölgesin saldı zemîne, îren râhat oldı sâyesine, ordu-yı mansûrelerin ve burc u bârûların ve 'asâkir-i zaferi'l-mücâhidîn sellemehümullâhü heft-i ser-su'bân misâlî delil ve nehâr-1 küffâr-1 bedkârın donanmay-1 muğrikalarına muntazır olub cevânib-i erba'aya rev tutub dem çekerlerdi. Ve cümle 'asâkir-i İslâm 'Arab u 'uryân dediler ki üstâd-1 kârhâne-i kadîm her ahadin kapây-1 bekâsın 7/tarz-1 'ademle muttarı etmiştir. Mi'mâr-1 ma'mûre-i cihân-1 mevcûdun bünyâd ve esâs-1 fenâ üzerine binâ örmüșdür ve bu fenânın 'îşından bize șehitlik hil'at-i cennettir deyûb Yâ Rabbenâ bu gazây-1 ekberin hasenâtına cümlemize müyesser eyle, ve menzil-i şühedâya eriştir, ni'metini müyesser eyle ve cennetü'l-me'vâlara derecemizi 'âlî eyle dest-i kûşâde-i dergâh-1 'izzet olub küffâr-1 bed-kârın rahnedîdeleri müterakkib olub Hak celle ve 'alâ Hazretlerine hamd ü senâ eylediler. Ol küffâr-1 hâk-sârın donanmay-1 mağrûkaları hangi sâ‘at-i meymûnede gelir ki ol dem-i la'lini şürb idûb kalb-i 'atşañnmı teskîn olsa gerektir, ve a'dây-1 düşmandan intikâm alsak gerektir dîrler idi, ve kemer kasd-1 küffâr1 meyân canlarına şöyle bend itmişlerdir ki dâire-i şefkat ve merhametten bîzâr merhale tașra gitmișlerdir. La'netullâhî 'ale'l-kâfirin. Ol küffâr-1 lacîn hangi evkât-1 hucestede pençe-i minkârımıza giriftâr olub bi-'avnillâhi Te'âlâ tekebbürlügün ve tuğyanlığın şikest ve muzmahil idevüz ve cümle 'asâkir-i İslâm nusretin dîdeleri râh-1 küffâra müterakkib iken ol melầîni hazelehümullâhü hâksârın müheyyâ olan donanma-yı mağrûkasına bilâd-1 menhûsaları limanından lengerlerin kal'u ref' idüp bâdyânların kûşâd idüp düvel-i şûr-1 'âlem bed-baht şûm-1 'azîmet dâru'l-cihâd ve makâm-1 evliyâ ve's-sâlihîne kasd-1 hizb idüp cumâde'l-'ûlânın gurresinde yevmûl-hamîs ve şehr-i Cezâyirenin on sekizinci günü bir heybet-i hâl ile geldi ki deryânın yüzü ol hâle müncer oldu ki gûyâ bir sahrâda remed-i gûz fend-i 'azim ihâta pây-1 tahtta rûy-1 zemînden eser zuhûr eylemeye, deryânin üzerinde ol donanmay-1 mağrûk küffârdan vech-i deryâ görünmez oldu, o küffâr-1 hâk-sârın 8/böyle tekebbürlük ve envâ-'1 heybet ile kendûy-i kahramân-1 cihân bilürsîn ve benim kahramânıma kûhulbûrz tâkat ve mecâlde 'âciz ola deyûb geldiği dâru'l-cihâd ve lütce-i medârul-kutb Cezâyirin mukâbelesine ki Tementus dâhil-i körfezine mukâbele-i vilâyete altı mil lâ-havfe ve bî-pervâ 'arza-i Cezâyir'e lenger-endâz olûb ejder bülend-i sefâyîn-i mağrûkaların bir dâire-i hivel çevirip bâkî sefâyin mihmanlarını evsatına ahz idüp râket eyledi, ol küffâr-1 melâ‘în bunu fehm eylemedi ki 'ömr-i tohumun hebâ-i fenâya gars eylemiştir. Sahîfe-i hikmet üzere kalem-i kudret ne yazmıştır, anı fehm eylemedi bu fikirden hâli oldular bir kimse bir emre şürû' k1la gerektir ki medhalin bildûgi gibi mahrecîn kezâlik bile ve her mühimmenin ağazında encâmına nazar idüp mikdâr-1 zarar ve nef'in mi’yâr-1 fikre itibâr ile temyiz kıla tâ kim renc-i beyhûde çekmeye ve tarîk-i teşebüsûnde âhir-i nedâmet tulû́ etmeye. Ve bir de budur ki kimin ki mürğ-1 hîmmet ve sûrh-i a'mâli ta'am ve kuvvettir. Zümre-i behâyimden mahsûb ve ma'dûddur. Görmez misin ki câyî bir para istihvâtla kânî olub bir lokma nân ile şâd olur, ammâ șîr-i 'âlî hemt-i berhûkûşı şikâr itmişken infâk-1 bir sâd-1 şikâr-1 kebîr görse yedîndeki şikârın 
şükrün bilmeyûb ferâgat idüp gayri sayda kasd-1 tama'-1 hâm ile kendûyi dâm-1 girdâba giriftâr idüp sayyâd elînde helâk eyler, ol küffâr-1 hâksârın fîkr-i şeyâtînlarına bu ka'de-i kadîmlerden bir şey zuhûr eylemedi ki 'arza-i dâru'lcihâd Cezâyir'e hâm-1 tama' eyledik. Şâyed ki tamâ‘'ımı mukâbelesinde şikâf-1 'arzu'l-Cezâyir'de vücûd-1 murdârlara kalır mı, yoksa selâmet bulur mu, bu fikirlerden bu'd oldular, ve taraf-1 İslâmiyede orduy-1 mansûrelerde ve vilâyet burcu ve bârûlarında ve cevâb-1 9/erba'ada ve tophânelerde hâzır ve müheyyâ olan 'asâkir-i nusret-şiâr küffâr-1 hâksâr1 gördüklerinde lâ-yu'âd kurslar eylediler ki î̀d-i ekber olmuştur. Hak sübhânehû ve Te'âlâ hazretlerine hamdü senâ ve şükür eylediler. Ve cümle-i ümmet-i Muhammed bu âyet-i kerîmeyi kırâat eylediler, va'fû 'annâ vağfîrlenâ verhamnâ ente mevlânâ fensurnâ 'ale'l-kavmi'lkâfirîn, ve dediler ki ol küffâr-1 melâ‘înin ve düşman-1 dînin 'asâkir-i murdarları hazelehümullâhü hangi vakit taşra ihrâc olur ki fî sebîlillâh-i Téâlâ cenge mukâbil olub bâd-1 süyûfla bahr-1 demi harekete getürüb tûfâna müstağrak idüp intikâm ahz idevüz. İnşâallâhû Te'âlâ ve 'avnullâhi Te'âlâ dîrler idi, el-hâsıl ol küffâr-1 hâksâr hazelehûmûllâh bu hâl üzere dâru'l-cihâd ve makâm-1 evliyâ-i Cezâyir'in mukâbelesinde meks ü ârâm eyledi, ol melâî̂nler 'aynı gayret ile cevânib-i erba'aya nazar idüp mîzânıyla kiyâs iderdi, ve mahalle-i mansûrlarda ve burc u bârûlarda mevcûd olan 'asâkir-i İslâmî deryây-1 muhît gibi mevc ve temevvûc eylediğin ve tophânelerde topçuyân ve 'asâkir-i İslâmla ta'mîr gördükde küffâr-1 müşrike-i bedbâht-kâr meş'ûm melậînin fikr-i murdârları lücce-i endişeye gark olub kendûlerin nihayet ve encâm-1 hâlleri yine müncir olsa gerektîr. Bir 'azîm belâyı hâristana uğradıklarını fehm eylediklerinde ol küffâr-1 hâksâr öyle tefekkür eyledi ki o kimse ki kendi kuvvetine i'timâd idüp bî-pâk ve bî-pervâ ola, lâ-cerem bu makûle kimesne kend ü kendûye tâbi olanları mehmâlığa ilkâ idüp tehevvûr ana sebeb-i helâk ola deyûb hırmen-i hayâtlarından nâ-ümid olub şu'le-i tuğyân tekebbür-i menhûseleri itfâ olub mütehayyır kaldılar ve fîkr ü endîşe-i fâsideleri bu mertebeye yetişti ki bizim cümlemiz dehân-1 tuğyân-1 effi ve yılanı 10/sinbâyı kendi yapımız ile dâhil olduk ve erlik oldur ki kendimizi şitây-1 şimşîrden sehl-i hâl ile yol bulavuz dedi. Eğer taşradaki cengâverlerimizi ve okçularımızı ve ceneral ve kumandan ceneralimiz sefîne-i sîneleri bâd-1 süyûf tûfâniyle lücce-i hûna gark ve helâk olmaları emr-i mukarrerdir, dediler ammâ el-âru eşeddü minen-nâr deyub kalb-i murdarları hızâne uğrayub kadide döndû, ve titremeğe başladı, merre zîde havfühûm bu hâli bu mînvâl üzere müşâhede kildılar. Rîşte-i ümidleri kat` oldu, ve lâkin elden gelir bir şey yoktur. Hemen kralımızın emrine tâbi‘ olub emr-i kral mûcibince hareket eylemek gerektir. Gâyet ile takayyüd itmek gerek. Tard-1 vilâyet içûn âmâde ve müheyyâ olan toplarımız ve sâir mühimmât âlâtlarımızı istihrâc idüp müstahak olanı yerli yerine vâz' idüp emr-i kralımız muktezâsinca hareket-i merdâne îdevüz. Belki bu varta-i dûzah-1 belâdan tahlîs-i cân îdevüz. Ve bunu dediler, tahlîs-i cân bulavuz çeh necât ya hedm ola şehr-i vücûdlar ya ola bir bâd, deyub ol küffâr-1 hâksâr-1 dâmen-i dermeyân idüp hallerin âmâde eylemeğe 
şürû‘ idüp ve nice haller âmâde ve nice sandallar ki dört yüz elli geminin ikişer ve üçer sandalı olur cümle sandalları hâzır idüp ve salların üzerine topların sâir metrîs âletleri ki cânı minnet merbût olunmuş bî-hisâb cümle levâzım-1 mühimmâtın sandallara inzâl idûb ve 'asâkir-i menhûselerin nâzil idüp hâzır ve müheyyâ eyledi. Cumâde'l-ûlânın leyle-i 'aşare leyle's-sebti nısfilleylden bed' idüp mühimmât ve levâzımın ve 'asâkir-i menhûselerin ve tâife-i şeyâtînlerin cûmle taşraya istihrâc idüp metrîslerin ve çarh-1 feleklerin 11/metrîslerine vaz idüp fîrâr eylediler. Bin beş yüz metrîs binası eylemek için âsitâne 'asâkirinden gayri metrîsleri leb-i deryâ olub ve metrîsler verâsinda deryâda fîrkateler ateşşerâr sekiz 'aded cümle seng-i âteş şiddetleri İslâm üzerine ve bu firkateler sâir kûhi bûlend. Sefâyinler tâ nehr-i harrâş nâm mahalden tâ Hamma nâm mahalle gelince her tophânenin mukâbilinde ikişer kûhi bülend-i sefîne ta'yîn eyledi ki hem doğancilar ile tard îde ve hem orduy-1 mansûreler ile tard îde ve hem 'asâkir-i Îslâmın Cezâyir'e rrhlet ve Cezâyir'den orduy-1 mansûrelere rihlet îdecek tarîklerin kat' eylemek içûn mu'în olunub küffâr-1 hâksâr subh-i sâdık tulû́una kadar her umûrın hâzır ve müheyyâ idûb tulû-'i âfitâba muntazır oldular. Gelelim taraf-1 İslâmdan kethüdây-1 mûkerrem hazretleri ve ağay-1 mükerrem hazretleri ve mîr-i mükerrem beğler 'asâkîr-i nusret-şi'âr Allâhu yansuruhûm cûmlesine rûy-i dahk ile ve 'izzet ile kemâl-i tekayyûd ile tenbîh olundu ki sakınub kûffâr-1 melấ̂̂ne kendünizi îzhâr ve âşikâr itmeyesiz ki ol müşrik-i laîn meydân-1 mû'rike bî-hâlî görüb tama'-1 hâmla fursat-1 ganîmettir deyûb leb-i deryâ metrîsler mahrûkalarından üç beş yüz hatve mesâfe mufârakat ola ve meydan kıtâli tîğlarına muvâfik vâsi' ve hâlî bulub yürüye. Bu hâl üzere 'asâkîr-i İslâm sehelallâhû şügûlühûm ve hafazallâhü 'aleyhîm emrü telyine zâbitânı yerine getirüb küllü hadd oldukları mahal-i mevzı'lerinde girân oldular. Ve dediler ki ol kimse ki eş-şöhretü âfetûn hâristânından havf etmeye mûddet-i kalb ile de külli murâda vâsıl olur. Tâ kim. Turse-i şeb-i târ ârız-1 simin. Nehârdan târumâr olub ğurre-i ğarrây-1 sabâh-1 dîdâr gibi âşikâre oldukda ol küffâr-1 hâksârın dîde-i murdârları 'âlem-nümâyı fark eyledikde cevânib-i erba'aya 12/kemâl-i 'aynı 'ibret ile nazar idüp Hammâ dağlarının üzerînde cem' olan 'Arab ve ve 'aryânî ve cemi' İslâmı gördükde kalb-i cîfelerine hûb-1 fîravn dâhil olub ecsâm-1 murdârların ra'şe ve lerzân olub rişte-i belâya uğradıkların fehm eylediler ve dediler ki peşte-i kûhde cem' olan 'asâkir-i Cezâyir bizleri çâsnnikîr-i hanzal süyûf itmelerine şüphemiz olmasin, dediler. Ol küffâr-1 hâksârın kibârları ki şeyâtînleri bir yere cem' olub dediler ki bizlere mevzi- ${ }^{-} 1$ muhâlifde meşakkat-1 firâvân ve belây-1 girândan gayrı başımıza bir tulû́ eyleyecek dav ${ }^{\varsigma}$ u fer ${ }^{\varsigma}$ yoktur, fevvâre-i dîdemizden âb-1 nedâmet-kesîr cârî olmadan bu teşyîl-i belây-1 girdâb gîrânın def'ine ve bu gâilenin ref'ine âteş şiddetinden gayri çâre ve tahlîs-i cân ider bu kadar duyub kat'-1 kelâm eylediler, ol küffâr-1 hâksâr kalb-i havf-i fîr'avn ile ve ergutan bârûya getürüb berren ve bahren bir âteş-i nemrûdu ifşân eyledi ki Allâhûmme Ahfaza's-Sâmi'ûn böyle âteşi dîde-i felek görmûş değildir, ve benî Âdem dahî sem“ itmemiştir, ki berren ve bahren bir kerre de sekiz yüz top imhâ olunmuştur, ve orduy-1 mansûrelerin 
üzerlerine deryâdan dört sefîne hamîre-i belây-1 âsumânîler endâhte idüp beyne's-semâ ve'l-arz âteş-i sûzânla memlû olmuştur, ve kethüdây-1 mükerrem hazretlerinin ve ağây-1 mükerrem hazretlerinin otağlarını pâre pâre eylemiştir, ve 'asâkiri'l-mücâhidîn emr-i uslûb muktezâsınca bir şahıs mevzi'lerinden ref-'i sır eylemeyub küffâr-1 hâksârın dîde-i menhûselerinden nîhân ve hafî oldular. Ol küffâr-1 melậîni'l-müşrikîn ve a'dây-1 dîn-i Muhammed hazelehümüllâhû metrîslerinden ref $f^{c} u$ sir idüp cevânib-i erba'ayı tecessüs idüp ve meydân-1 mu'rikeyi hâlî gördükde girdâb-1 hayrette kalub fikkr-i murdârına bu geldi kim, değildir ızhâr ne lâzımdır ibâret, ki 'ârif olana besdîr işâret, deyub 13/tevâfuk eyledi. Ol küffâr-1 melậ̂inin fîkrine bu geldi ki bu meydân-1 hengâm-1 belâda bir sadmet-i tûfâna ilgâ olsak gerektir ki keştî-i vücûdlarımızdan eser kalmasa gerektir, dedi. Gelelim ki taraf-1 İslâma mîr-i mükerrem Salih Beğ kethüdây-1 mükerrem, ağây-1 mükerrem huzûruna gelub âdâb ve erkân-1 devleti yerine getürûb du'â ve temennâ idüp kelâm eyledi ki, olur hikmetle hâsil her dîl, olur hikmetle hal her emr-i müșkil, düșman serkeși meydân-1 kıtâlden rücû' eylemez illâ nâz-1 bâz-1 şimşîrden gayri ile dedi, ve men yü'til-hikmete fekat ûtiye hayran kesîrâ, lütf ü 'inâyet idik bu bâbda ta'accül eylemeniz sabr u ârâm, sibâs-1 minnet bendenizdir zîrâ hâzır ve müheyyâ olan cem'iyyet cümle bu mevzi-'i celîleye gelmiştir. İnşâallâhürrahmânirrahîm 'asâkîr-i zaferu'l-mücâhidîn sellemellâhü ve cümle ile tevekkeltü 'alellâh küffâr-1 hâksâr düşman-1 dînin üzerine hücûm idüp metrîs pâyelerin lâne-i 'usfûr gibi târ u mâr eylemek 'alellâhi Te'âlâ emr-i mukarrardır. Ve bir miktar mekes buyurmanız hayru â‘âdır, küllü hayrın olduğu ma'lûm-1 sa'âdetinizdir, deyub 'azîm du'â eyledi, demişlerdir ki, derecât-1 şerefe terakkî zahmet-i kesîr ile olur kethüdâ-y1 'âlî makâm ve ağây-1 zîşân tûli 'ömruhüm bu râiden beri ma'kûl ve ahsen gördüler, ve tedbirlerin kavâ‘id-1 sıdk u ihlâs üzere urdılar 'alellâhi Te'âlâ bu melấ'inlerin 'azâb-1 elîm ile ve şiddet-i süyûfla helâkleri emr-i mukarrardır didiler. Gelelim ki ol küffâr-1 hâksâr metris lânelerinden keyfe-mûş re's-i murdârların ref' idüp cevânib-i erba'aya nazar eylediklerinde, görülür ki mîr-i hûr-1 mükerremin orduy-1 mansûresinden 'asâkiri zafer-i nusret vallahü yansuruhüm kırâat-1 feth-i şerîf ile sancaklarnn kûşâd idüp mîr-i hûr-i mükerrem ma'an 'asâkir-i nusret-şicâr ile peşte kûhi bâb-1 cedîdden gülbank-1 Muhammedî ve sadây-1 tevhîdi semâya 14/'urûc iderek 'ankâ-i 'ukâb gibi feth-i cenâh idüp intikâm-1 düşman ahzîne gelürler, ol küffâr-1 laî̀n hazelehümüllâhü bunları bu muhriket bu șecâ'at, bu heybet ile geldiklerini gördükde kalb-i murdarlarına şiddet-i renç dâhil olub ecsâm-1 murdârlarına 'azîm lerzet ahz idüp fikri şeyâtînleri bu menzile irdi ki bizlere bu mekân-1 muhâtaradan semt-i selâmet kalîldir. Ve bu peşte-i kûhdan tuyûrlanır gibi bâl-i pervâz idüp gelürler bunların bu hareketleri ve bu cünbüşlerinden tulû́ eyleyen budur ki nerm-i cümlemizi dârûy-1 süyûf ile lâ-ya kil idüp hirmen-i 'ömr-i fânimizi erzen gibi bâd-i hevâya vermenizde bir şek yoktur dediler. Allâhu zîde havfehüm ol küffârlar fikr ü endîşe içre ğats idüp dedi ki; bunlar bizi kendilerine nevâle-i muhtasar ve mahkûr gördüler, lâkin bunların gâile-i cû‘ların et'ımetûn- 
nâr itmek gerektir deyub ol kûffâr-1 bî-dîn ve melậîn yine bir âteş-i nemrûdu saç dı ki el-'iyâzû billâhi Te'âlâ dil ile takrîr ve kalem ile tahrîr olunmak imkânda değildir. Ve seng-i müdâfa'a hangi cebel ü kûha ilkâ olunduysa kûhi sengi cenâh-1 tuyûr gibi âsumâna tayr eylerdi. Ve humbara-i belây-1 âsumânî tarafindan endahte idüp nihâb gibi şihâb gibi nâzil olurdu. Ve toplar ve hamîrelerin hisn-1 sadây-1 efsûnu cebel ve sahrâlara münşer olub kûh-i sahrâ ve çöllerin her tarafı bir gûne hey'et bağlamıştır. Ve demişlerdir ki her kimesne meydân-1 kıtâlde kemer gayreti meyânına hazm ide. Bu mahv ile 'asâkîr-i İslâm bu kûffâr-1 la înin târ-1 nemrûduna tahammül idüp sabr eylediler. Her kim rencü mihnete tahammül eyledi devlet ve ni'met murâda irdi dediler. Ve dediler ki seng-i girânı rûy-i zemînden irtifâa meşakkat-1 fîrâvân gerektîr. Ve endahte olan belây-1 âsumânî humbaraya ve şîddetûn-nâra ve humbara-i hevâyî misillü toplar derûnunda humbara-i sağîre endâhte olunur. Ve misketü’l-müdâfí bârân ve matar 15/nâzil oldu. 'Asâkîr-i nusretü'l-mücâhidîn bu ateşlerin cûmlesine sabr idüp girân oldular. İnşâallâhürrahmânirrahîm ol küffâr-1 la înin şehr-i vücûdlarından müş̧'ll olan 'ömr-i kandillerin bâd-1 süyûf ile itfâ olmak mukarrardır, dediler. Ve ol küffâr-1 hâksârın mukâbelesinde kethüdây-1 mükerrem sifât ve ağây-1 şecâ'at behrâm-1 süvâr esb-i ceyye ve cevşen heybetü'lbedrü'z-zamân ol mevz1-'i celîlede 'asâkir-i nusret şicârın önünde tevakkuf idüp sedd-i meydân-1 mu'âreke oldular. Allâhu yansuruhûm, ve dediler ki, çûn kader tîrûn ân kavs-i fezâ, siper olmaz âna meğer ki r1zâ, tevekkeltü 'alellâh olalım şöyle bilelim ki dîvanhâne-i ezelde fermân-1 fezâ cîrbân ne bulmuş ola ve duhter kadar da rakam-1 ceffel-kalem müsbit ve muğrır olmuş ola deyub ve ol küffâr-1 bed-girdâr-1 la în meydân-1 muhârebeyi bu gûne hâlî görüb endîşe-i bahr-i fîkre gark olub dedi ki ey hâksâr-1 rûtbe-i rûzigârı ben bilirim ki âba i'tîmâd ve havaya istinâd 'âciz değildir, demişlerdir ki bu 'ömre vüzûr-1 bâzûya inanma ve rüzgâra aldanma ve suya dayanma, bu meydân-1 mu'rikenin sâhibleri hangi cânibe teveccüh eylediler ki bu meydân-1 mu'rîkeyi hâlî kodular. Bunların kasd u fikirleri ümmet-i mesîhâna ve tâife-i hıristiyâniya bir belây-1 teşyîl ve duzahları kurulmuştur ki bu meydân-1 muhârebeyi hâlî komuşlardır, dediler. Ve yine ol küffâr-1 bedbaht dediler ol kimse ki hâlet-i hayâtında bed-nâm düşman-1 kâm ola, nâm-1 cerîde-i ihyâda kitâbet değildir. Ol küffâr-1 hâksâr tabl-1 nefîrlerin mezheb-i fâsidelerine görecek harbîlerin dögûub bandıraların metrîs nekbetlerinden ref' idüp yirmi bir bin 'asâkîr-i murdârlarılyla ve bin sekiz yüz garâtadır ki el humbarası endaht iderler. Ve her bir garâta 'asâkîr-i murdârlarının önünce ref-'i pâ idüp yürümeğe başladı. 'Asâkîr-i İslâm küffâr-1 16/hâksârın hareketin görünce dediler ki 'ibâd-1 sâdıklarına destgîr olub Hak celle ve 'alânın 'avn ü nusret ve 'inâyetiyle bu güne bu meydân-1 küffâr-1 la'înin lahm-i cîfelerin kâffe-i vuhûş ve tuyûr ve bu'ûş ve büyûr ve mâr ve sadpâye ve şiğâle ve rubâh-1 ziyâfet etmek gerektir. Ol küffâr-1 melâîin hazelehümullâh yine berren ve bahren bir âteş-i şiddet dahî saçtı ki ma'âzallâh kürre-i 'âlem gök duman içinde kaldı ve 'asâkîr-i küffâr-1 la'în rûy-i zemîne yakın idüp ref-'i pâ eylemeğe mecalleri kat' olub ve bu menhûselerin ra'şa-i lerzânı ahz idüp devha-i 'ömûrleri bâd-i hizâna 
uğrayub hengâm-1 zemherîre ve kendilerinin tiğ-i sâm-1 vizâle giriftâr olduklarını fehm eylediler. Ve ol küffâr-1 hâksâr dediler ki her kimesne ki pâsure küşûr-1 ğayra olmak mukarrar vücûdu Hak sübhânehû 'azze ve celle pây-1 küffâr-1 dâme girdâba giriftâr eyledi. Elhamdü lillâhi hamden kesîran. Bu küffâr-1 hâksâra şerbet-i hanzal merâret-i şimşirden gayri devâ yeter değildir, dediler. Allâhü Te âlâ mu'înimiz ola, âmîn. Ol küffâr-1 lacîn ayak ayak gelmeğe başladıkta 'asâkir zafer-i nusret-i küffârın bu hareketin gördükde bir ferdin sabra liyâkatları kalmayub hücûm eylemeğe hareket eylediklerînde zâbitân tûli ‘ömruhüm 'asâkiri zaferi'l-mücâhidînin hareket-i şecâ‘atlarını ve şîr-i merdâneliklerini görûb tesellî idüp Hak Sübhânehû ve Téâlâ bu hengâm-1 mukâtelede ol küffâr-1 la înin küllei hâr-kilâbları kürre-i zemîne yeksân olmaları emri mukarrardır, dediler. Hazreti Hak Celle ve 'alânın 'avn ü 'inâyetiyle tarrây-1 'ömürleri tayy olmaları garibdir. Ve metrîsin şebân-1 penahlar1 târumâr olub hayyât-1 süyûf câme-i sürh piçmek mukarrerdir, dediler. İnşâllâhûrrahmânirrahim, es-sabru miftâhul-harc dediler, ol küffâr-1 lain bir mikdâr leb-i deryâdan müfârakat eyleye. Ol küffârın hûn-1 murdârları vechi'l-'arza şitâ-i matar misilli revân 17/olmak mukarrardır. Bi'avnillâhi Te'âla, ol küffâr dîn-i düşmanın 'asâkir-i menhûselerinin önünde bin sekiz yüz garâtadır ki humbara-i dest-i endâhte iderler. Nâr-1 nemrûd-1 şedîd ile berren ve bahren İslâm üzerine yürüdü. Ol vakt ü sa'at-i meymûnede zâbitân sellemehümullâhü 'asâkiri nusretullâhi zîde hayruhûm düstur olub pençe-i şîrâna ve kendi âver-i meydân-1 şecâ'at ve sifatu'l-mûcâhidîn Allâhu yansuruhüm heft-i ser-şa'bân-1 mânendi gûyâ hâbeden ser-kaldırub kûşâd-1 çeşm eylediklerinde cümle-i gâzî serdengeçtiler dâğâyı ve kılınçlar yaya tevakkuf olub ve 'alemdârlar 'alemlerin ref' u set idüp yer yer sûre-i feth-i şerîfler kırâat olunub ve salât-1 şühedâ edâ olunub ve cûmle 'asâkir'l-mü'minîn tecdîd-i îmân ve istiğfâr eyleyub sultânu'l-enbiyâi ve tâc-1 asfiyâ resûlullâh sallallâhû Te'âlâ 'aleyhi ve selleme salavât-1 şerîfeler getürülüb Hak sübhânehû Te'âlâ Hazretlerinin birliğine tevekkül olub gülbank ve tekbîr getürülüb Allâhû ekber ve Tevhîd sadâsı 'arşu'rrahmâna erişüb 'asâkiri'l-mü'minîn tilâvet-i Rahmân eylediler. Fe li'llâhil-hamdü ve'l-minne, fallâhü hayrun hâfîzâ. Ve hüve erhamûrrâhimîn, dediler. Ol vakit melâike-i seb'u's-semâvâti femmel-mü'minînden ihrâc olan kelime-i tevhîdi ve rahmeten li'l-'âlemîn habîb-i ekrem ve resûl-i muhterem sallallâhü Te'âlâ 'aleyhi ve selleme olan salavât-1 şeriffeleri sem' idüp cümle sükkânü's-semâi ve'l-'arzı ümmet-i Muhammed'e du'âlar idüp tekbir getürüb Yâ Rabbenâ bu kullar habîbinin sâdık ve hâs ümmetleridir ve onlara farz eylediğin gazâda cümlesini emr ü fermânına mutî́ olub kendü lütfu kudretinle 'atâ ve ihsân eylediğin rûh'azizlerini fî̀ sebîlillâh fedâ ve kurbân etmişlerdir. Ya Rabbenâ rahmetinle 'avn ü 'inâyet ve nusretler ihsân eyle. Yâ Rabbenâ ve senin birliğine tasdîk ve habîbine imân getürüb sâdıku'l-va'd olan kullarını senin birliğini 18/tasdîk eylemeyen müşrik kullarının üzerine gâlib eyle deyû dưâ eylediler. Ve sadây-1 gülbank tevhîd-i sem-'i gûş-1 nisvâna ve sıbyâna ve şeyhâna dâhil olunca cümle teveccühi dergâh-1 'izzet olub re'slerîn 'uryân ve ciğerleri püryân ve destleri kûşâde Yâ 
Rabbenâ hürmet-i evliyâ ve hürmet-i sulehâ ve hürmet-i 'ulemâ ve hürmet-i enbiyâi ve'l-mürselîn ve hürmeti habîbin ve resûlün Yâ Rabbenâ cûd-1 feyz ü kereminle ümmet-i Muhammed'e nusretler 'inâyet eyle deyû dîdelerinden nehr-i dâr-1 mev'alar cârî olarak Hak Celle ve 'alâya tazarru' ve niyâz eylediler. Hak Celle şânühû ve 'âmme nevâlühû velâ ilâhe ğayruhû sıbyânların ve şevâyih ve acâyizler ve cümle mü'minîn ve'l-mü'minât du'âların müstecâb idüp ve mevz1-'1 celîlde hâzır olan melâiklerin tazarru' ve niyazların kabûl idüp ehl-i İslâma 'inâyet ve nusret-i kesîr 'atâ ve ihsân eyledi. Elhamdü li'llâhi ve'l-minne, ve cümle ümmet-i Muhammed derûn-1 kalb ile bir ağızdan bâkıyât, sâlihât zikr eylediler. Sübhânellâhi ve'l-hamdü li'llâhi velâ ilâhe illallâh vallâhû ekber velâ havle velâ kuvvete illâ billâhi'l-'aliyyi'l-'azim, lâ ilâhe illallâh Muhammedün Resûlullâh, vemâ Muhammedün illâ resûl, ve âminû bimâ nezele alâ Muhammed, vekelâ billâhi şehîden Muhammedûn Resûlullâh, deyub ol küffâr tâife-i şeyâtîn-i melâ‘în hazelehümullâhü mukâbelesine sed olub tevakkuf eylediler, ve dediler ki, Yâ ilâhi kıl müyesser bize cennet-i a'lâyı, şefí' kıl rûz-1 mahşerde sâhibi'l-hamd-i livâyı, ol melậ̂̀n-i bed-kâr 'asâkir-i İslâm nusretin böyle hareket ve şecâ'at ve heybet ve cesâretlerin 'aynı ibret ile gördükde endişei muhîte düşûb fikr eyledi ki bizim cümlemiz bahr-i tahrîse gark tama'‘ hâmiyle bu varta-i süyûfa düşdûk bu varta-i belây1 sâha-i süyûftan sâha-i selâmete vâsıl olmamızda nice hıristiyanlar 'ömr-i tahmın kürre-i zemîne ğars itseler gerektîr, dedi. Her kim 'adüvvisin eyleye tahkîr, gör ben anıyla 19/eyleye tahzîr, bu fikir üzere melấîni'l-müşrikîn tevakkuf eyleyûb muhayyer kaldı. Hazelehümullâhü 'ale'l-müşrikin ol küffâr-1 hâk-sâr böyle mütehayyir ve bî-mecâl gelür iken mîr-i mükerrem Sâlih Beğ kethüdây-1 'âlî-kader ve ağây-1 mükerrem kendi ma‘iyyetlerine gelub âdâb-1 devleti yerine getirüb ve sâir beğler kezâlik ve halîfe-i garb âdâb-1 sa'âdeti yerine getirüb tevakkuf eylediler. Ve mîr-i mükerrem Sâlih Beğ ve mîr-i mükerrem Tatra beği ve halîfe-i garb ve cümle 'asâkiri'l zaferu'lmücâhidîn ve'l-muhzıru'l-makâm dest-i kûşâde idüp Hak Sübhânehû ve Te'âlâ hazretlerine tazarru' ve niyâz eylediklerinden sonra Hazret-i Mehmed Paşa ve dâmellâhü 'ömrahû ve devletühû âmîn. Ve kethüdây-1 mükerrem ve ağây-1 mükerrem hazretlerine ve cümle 'asâkir-i nusreti'l-mücâhidîne du'â ve senâlar eyleyub ve ba'dehû şehinşâh u 'âlem-penâh halledellâhü hilâfetehû ilâ yevmi'lk1yâm hazretlerine ve nusret-i devletlerine du'â ve senâlar olunduktan sonra düstûr-1 taleb idüp dediler ki, Allâhû yansurunâ ve yansurukûm. Bu mevzû‘da hâzır olan cemî̀yyet-i cümeli meydân-1 muhârebeye sürmenin vaktidir. Ve cenân-1 dible gaflet tahmın ğars etmeyelim. Tevekkeltü 'alellâh 'asâkir-i zaferlerin ardinca bugün bu meydân-1 şehâdette ve bu mahkeme-i cidâlde kâzî-i süfûy-1 Muhammedî bu meydânı bekler fî̀ sebilillâhi te'âlâ kesti-i vücûdumuz rahmete müstağrak idelim dost-1 hûrândan hedâyâ-i ni'am1 ve şarâb-1 kevseri nûş idüp derece-i firdevs-i 'âlî bulalım, dediler. Ol mevzû-'u celîlde ve ol meydân-1 kıtâl-i hucestede kethüdâyı mükerrem sıfât-1 bedrü'z-zamân ve ağây-1 mükerrem-i şecâ'at süvâr olub şiddetü'n-nâr a'dâya rû be rû sedd-i iskender oldular. Allâhu yansuruhüm, ve ol eyyâm-1 meymûnede ricâlu'llâhü’l-ğaybü’l- 
bâcîde olub ümmet-i Muhammed'in muştusunda olub emrullâhi Te‘âlâ 'azze ve celle İslâma 'avn ü nusretlere ihsân eyledi. Düşman-1 hâksârnn mukâbelesine geldiler. 20/Nusret İslâma düşdü, ol vakit sa'îdde sa'at müşter-i mübârek idi. Ol vakt-i mübârekde 'asâkir-i İslầma düstûr olub mîr-i mükerrem Sâlih Beğ süvâr-1 esb ve mîr-i mükerrem Tatra Beği ve halîfe-i ğarb cümlesi 'ankâ-i kâf gibi 'asâkîr-i șieârın ve İslâm nusretin verâsınca ve sipâhiyân-1 zafer bir taraftan 'asâkir-i 'aryân ve 'arab bir cânibinden ol küffâr-1 la'înin mukâbelesinden darb-1 cemel olunub cümle 'asâkir-i İslâm ve ümmet-i Muhammed sağîr ve kebîr bir ağızdan, es-salâtü ve's-selâmü 'aleyke yâ rasûlallâh, es-salâtü ve's-selâmû 'aleyke yâ habîballâh, es-salâtü ve's-selâmü 'aleyke yâ sâhibi'l-livâi'l-hamd yâ sâhib'şşefấati deyûb herkes sancakların ref' idüp gülbank-1 Muhammedî Allâhû ekber sadâs1 seb'at's-semâya vâs1l olarak ol küffâr-1 hâksârnn üzerîne fî sebîlillâh mânend-i zâl-i zamân ve heybet kahramânı hücûm idûb berk-i hâtıf gibi küffâr-1 melậînin üzerine bir kat âteş-şerâr ve tophânelerden âteş ve seng-i müdâfa'alar remy olub ol tâife-i șeyâtîni 'aleyhimilla'neti ilâ yevmi'd-dîn şehâb-1 semâvi ile recm ve şerâre-i şihâb âteş-pâre vücûd-i mel'anet-i âlûdeleri sûz-1 hâkser olduğu gibi el-mücâhidîn nusret-i İslâmın âteş-şerârları ve remy olunan serb-i simleri küffâr-1 la îni şehâb-1 misl-i vücûd-1 murdarların harf u şûyi idüp hâkestere döndûrdû. Elhamdü lillâh ol küffâr-1 la'în 'asâkir-i şeyâtîne endahte olan âteşi ve topları görûb hayât-1 fânlerînden nâ-ümid olub tekbîr ve tevhîd sadâsından 'akl-1 küffâr kayb olub cümlesi medhûş olub mukâbele-i İslâma tevakkule mecalleri kat' oldu. Ol ordugâhda 'asâkîr-i küffâr-1 la în bî-mecâl kalub 'asâkîr zaferallâhü yansuruhüm küffâr-1 lacîn ile mülâkî olub küffâr-1 hâk-sâra öyle bir kılıç 21/vurdular ki fî sebîlillâh melâike-i sipihr seyrânların eyleyub tahsinler itmișlerdîr, ve ol tavâyif-i merdûd hazelehümullâh. Süyûf-1 İslâma tâkat getirmeyub metrîs-i menhûselerine rucû- ${ }^{c} 1$ red idüp ol küffâr-1 hâksârin tekebbürlükleri berk-i şimşîr ile şîkest olub şiddet-i nemrûdları nârları âteş-i tîğ ile itfâ olub istihlâs-1 firârlarında küffâr-1 bed-kârın ilerû gelen güzîde el humbaracıları kürre-i zemîne ser-nigûn olmuşlardır. Ol kâr-1 zârgâh-1 kıtâlde pençe-i küffâr-1 bed-kârın ecsâm-1 murdarları sühte olub üstûhvân-1 habeşîleri fevkaz-zemîn olub duhter-i hayatları tayy olub finnâri lezâ oldular. Şimşîr-i şiddet görûb nâ-ümid oldu la î̀n, hûn-i ebdân tersâdan lâle-renk oldu zemîn. Ve nice gâziyân sebüksâr olanlar küffâr-1 hâksârın metrîs-i penâhîlerine dâhil olub melậînlerin kelle-i kilâbların ecsâmından cüdâ idüp pelk-i murdârından ref‘ idüp selâmete gelmişlerdir. Ve nice sipâhiyân nusret-i rahşların metrîs-i küffâra behrâm-dâr dâhil olub talân u târumâr etmişlerdir. Küffâr-1 hâksârın dîrest-i nizamları perişân tabl u nefîrleri ve bandıraları pây-1 İslâmda surh-1 hûne âlûde olub kaldı, rif'ate ferd û kimesne dest urmadı, ol küffâr-1 bedbaht-1 şümun bir cenerali her serb gâziyân ile yek pâyi murdârı şîkest olub serce-i rahşândan kürre-i zemîne ser-nigûn old1. Hayyât-1 rûzigâr ol belîd-i lacîne bir hil'atünnâr bicdîgi cem'iyyet hırmen-i hayâtı cemre-i sefer ile harf olub cân-1 nekbetin nuzzâra irsâl eyledi, meseldir ki kanâ'at ehli olmayan dünyâda râhat bulmaz, 
ferâğat kadrîn bilmeyen 'âlemde 'âkıbet bulmaz, ol mel'ûn idi, 'âkıbet fenâsın sevf ü sipâsında rahiş̧-î bahâ ile 22/bey' eyledi, pençe-i rûzigâr giribânından tutup kürre-i 'arza sergûn eyledi. Ve deryây-1 süyûf temevvûc idüp keşti-i vücûd1 murdârın ğark eyledi. Elhamdü lillâhi'l-'aliyyi'l-a'lâ sübhâne'l-kâdiru elkudretü'l-ekremü'l-kerîm sübhâne'l-celîlü'l-'azîm sübhâne'l-hâdî men yeşaü sübhâne'l-ğafûru'r-Rahîm ilallâhi hamden kesîran ol küffâr-1 hâksârın 'asâkir-i cem'iyyet tavâif-i şeyâtîn-i lacîn bu hâli görüb remesîne kurd girmiş güsfendân gibi kendûlerini tahlîs-i cân deyub metrîs cân-1 menhûsaların şaşırıp belây-1 girdâba uğradıklarını bilmeyub deryâdan kendilerini bahre ilkâ eyleyub ğark olabilir ve nice küffâr-1 la în berk-i süyûf ile rûy-i zemînde kalmağa başladılar, ve beynlerinde 'azîm feryâd u nâle zuhûr eyledi ki hadden birden oldu. Elhamdü lillâhi'l meliki'l-mu'în ve bu âyet-i kerîmeyi okuyub hamd ile bu âyet bizlere 'azîm huccettir ki bu gazây-1 hasenâtı destimizde şîkest olmaz ve her murâda ermeğe sebeb olduğunu ve her matlûba ermeğe vesîle olmasindan şek ve şüphe yoktur dediler, fekadis-temseke bi'l-urveti'l-vüskâ, sipâs-i minnet ve şükür ol gird-kâra ki böyle bir tekebbür sifât-1 şeyâtîn-1 melậ̂̂ni dest-i şimşîr-i İslâmda zelîl ve makhûr ve münhezim eyledi, ve her cânibi şikest olub bî-mecâl kaldı. Her kimesne ki mukarrab-1 kûşûr-1 gayri ola, 'azâb-1 elîm ve belây-1 girdâbdan hâlî olmaz, demişler. Ol küffâr-1 hâksârın cenerali olan pelid-i la în şeytân-1 'asâkir murdârlarının çekilub kilablar gibi penç eylediklerin veya süyûfla çûbâd-1 perîşân hâl olduklarını gördükde âteş-i gazab bünyâd-1 sabrın târumâr idûb meklûb-i sek gibi kâh kalkar kâh oturur ve pençesiyle rûyî hâkî hirâş idûb ve zemîne urub dedi ki bu fitneyi bize ve bârûn-1 şiddet ve bu âteş-i şiddet 23/belâyı bezyâl kılandır, âfitâb-1 heft-i deryâ ile itfâ olmak muhâldir, ve dârât ve devlet-i İspanya'yı heder idüp harâb ve rüsvây eyledik. Ve bir tâc-1 vakâr sâhibi kralın çehre-i beyâzın küsûf-1 âfitâb gibi siyah eyledik. Ve bu ol melâ'în-i endîşeye ve 'azîm fîkre gark oldu. Allâhû zîde meşfetehüm, ol 'asâkîr-i şeyâtînin niceleri seng-i müdâfi' ile tuyûr misillü beyne's-semâil 'arza pervâz eyledi. Ve niceleri serb-i gâziyân ile cerâd gibi hâk-i zemîne tahiyyât eylediler, ve 'asâkîr-i zaferu'l-mücâhidînin Allâhû yansuruhüm âteş-i sinân tâbdârları hirmen-i hayât a'dây-1 bed-gîrdâr1 bâde vermiştir, ve kâş̧e-i küffâr-1 füccâr taht-1 pâ olub dükle yek dirhem bey olunmuştur. Elhamdü lillâhi ve'l-minne ve kethüdây-1 mükerrem Sâlih Beğ ve mîr-i mükerrem Tatra Beği ve mükerrem halîfe-i garb ve 'asâkîr zafer-i nusret-i küffâr melâ̂înin üzerine 'ankây-1 kâf gibi bâl açub cevelân idüp küffâr-1 hâksâr1 perîşân ve nâlân idüp ol bed-girdâr-1 la înlerin keşti-i vücûdları bahr-i mihnete gark olub hasret-i fenâ oldular, ve nice hınzîr-i mel'anet hârın kilâblarını ecsâm-1 murdârlarından kat'u cüdâ eylediler, ve rodaları remîl ile behrem-i şûd oldılar. Ve bî-hâb-1 mecrûh küffâr kendülerin metris-i menhûsü penahlarına illkâ eylediler, ve nice küffâr-1 melầîn mevz1- ${ }^{\circ} 1$ mu'ârekde mukarrabü'l-vech kalub harekete liyâkatları olmayub tu'me-i şimşir-i gâziyân oldular. Elhamdü lillâhi Te'âlâ destgîr ve mu'înlerimiz olub bâkî küffâr münhezim ve hüsrân kalub dîde-i küffâra envâ-'1 'alâmetler zâhir olub hayât-1 fânîlerinden nâ-ümid oldular ve beynlerinde olan nâle ve fîgân beynessemâi 
'arza sed çekmiştir. Allâhü sübhânehû ve Te'âlâ kendü kudret ve 'inâyetiyle ol eyyâm-1 hengâm-1 mu'ârekede cânib-i şafaktan hava 24/müteğayyir olub nısf-1 kubbe-i sipihre gelince bir zulumât-1 esved ve zerîk u hamrâ ve gûnâ-gûn semâda kudretullâhi ğamâmlar ve ra'd-1 şedîd ve berk ve sâikalar küffâr-1 şeyâtînler üzerine nâzil olub küffâr-1 la înler kendilerine kudretullâh nâzil heybet-i semâyı gördüklerinde şiddet-i süyûfdan bâkî mütefekkirelerin zulümât-1 ğamâm-1 heybet-i sipihrden perişân eyleyûb ve kilıçlar bir taraftan küffâr-1 hâksâr1 silsile-i belâya giriftâr eyledi, ve zenbûr-i sebâset üzerlerine nâzil olub göz açtırmadi. Nasrun minallâhi ve fethun karîb. Ol küffâr-1 laî̀nlerin şiddet-i tekebbürlükleri tâ zebâna şimşîr ile teskîn olub ve ecsâm-1 murdarları şâne-veş hurde olûb ser-nügûn olmuşlardır. Elhamdü lillâhi'l-vehhâb sükkân-1 heftu'ssemâi ve kürre-i zemîn üzere ihzâr olan melâikeler seyranların idüp fî sebîlillâh bu gazây-1 ekbere tahsîn ve ta'accub idûb 'azîm-i ferhunde-kâl olmuşlardır, hamden ve kesîran ol küffâr-1 hâksârların cerân-1 la'îni 'asâkîr-i murdârlarının bend-i giriftâr silsile-i tîğ olub perîşân ve nâlân görub endîşe-i fikirde mütehayyir kalub 'akl-1 fâsidesi buna erdi ki bîze sunulan dârûy-1 ecel def'îne Bukrât-1 zamân ve calinus-1 devrân olsa bu hicrânın dermânında âciz ve hayrân olub fikr-i ezeliyesi târumâr ola. Bizim üzerimize sâyebân olan 'ankâ-i zulümât-1 süyûftan ne tarîkle bir selâmet ve istihlâs-1 cân bulavuz, dedi. Yoksa sarsar-1 rûzigâr dıraht-1 ömrümüzü bu mekân-1 muhâlifte mecyûb-1 dendânından ihrâç olan muhâlemizi tınâz-1 harman gibi savurmak mukarrardır, dedi. Açılmaz bu dîdemiz nice gam efkâr-ile, düşmüşüz bir hâristâna ağlayam beğ zâr-ile, dedi. Havf-i şedîd ile cesed-i murdârların 'aşere-i firâvân ahz idüp 'akl-1 menhûsanın perîşân eyledi, ol küffâr-1 şeyâtînin $\underline{\mathbf{2 5}}$ /'asâkîr-i nekbetleri böyle havf-i hareketîn ve perîşân hâlin, murdarlarına nazar idüp levh-i pişânîlerinde kitâbet olan mevtlerîn ba'dühüm 'alâ ba'd âşikâre gördûklerinde ve kendilerinin pençe-i sabbâ ve tîğ-i İslâmın minkârına şikâr oldukların fehm ü idrâk eylediklerinde cümle tavâif-i küffâr feryâd u figân idüp cevâb eylediler ki bizi bu sevf-i sebâseti ecele dâhil eylediniz, biz bu metâ-'1 'ömr-i fânimizi bu sevf-i süyûfda rahîs-i bahâ ile itmeyüz ve bizi bu girdâb-1 musîbet-i süyûfa nîce giriftâr eylediniz ise bu varta-i cezâdan bir tarikle 'ömr-i fânimiz bâd-i hevâ olmazdan mukaddem istihlâs-1 cânımıza bir tedbîr idüp bu bahr-i tûfân-1 süyûftan bir kenâr-1 selâmete irevüz biz canımızdan nâ-bedîd olduk. Maksûd-1 rücû'umuza vâsıl olmayub bu mevz1-'1 muhâtarada cümlemiz helâk olmak mukarrardır deyub tekrâr feryâd u ğaryü eylediler. Ve dediler ki bu mevzu'da bu şiddet-i musîbet tî̆g-i cezâ ile harman-1 'ömûr tınaz misillü savrulub hayât-1 bâkîmizden dîde-i cihân eser görmeğe, ve eğer bizi bu varta-i belâyı teşmîrden halâs eylemezseniz destimizden âlât-1 harblerimizi remy idüp esîrliği kabûl idûb tahlîs-i cân idevüz deyub kelâmların kat' eylediler. Ol küffâr-1 melấîn-i cenval-i 'asâkir cîfelerinden böyle kelâmı gûş idüp 'akl-1 murdârın tâlân idüp rûy-i nekbetîn hâk-i mezellet sürûb hûnâbe-i hasreti fevvâre-î dîdesinden revân itdi, ve sarsar-1 hayret ve harmân-1 hırmen sabır dâiresin savurub bâd-1 hirân içinde kaldı. Dedi ki sihâbî. 
Bu ğamâm-1 ğumûm ve tûfân-1 zulumât-1 hümûmda kaldık. Ol sâika-i tî̆g-i şiddet tâ başımız üzere yanıldı şimden gerû ne lâzımdır görelim deyub kaldı. Elhamdü lillâhi'l-ğaniyyi'l-hamîd ol hallâk-1 cihân ve rezzâk-1 'âlem-i Hak Celle ve 'alâ şânihî 26/ve 'amme nevâlihî velâ ilâhe ğayruhû ümmet-i Muhammed'e kerem ü du'âda bulundular. Rahmet idüp nusretler ihsân eyledi böyle bir mağrûr ve mütekebbîr düşman-1 dîn-i Muhammed olan müşrikîn hazelehümullâhü kavî düşmanı habîb-i ekrem sallallâhü Te'âlâ 'aleyhi ve sellemin âb-1 rûy1 hürmetine müşriklerin başına dünyâyı tenk idüp cem 'iyyet ve tedbîrlerin perîşân ve tâlân idüp a'dây-1 dîn olan Cezâyir'in taht-1 şiddet-i süyûfta hazelân ve helâket idüp makhûr ve münhezîm idüp ta'âm-1 ka'r-1 deryâ eyledi, ve Muhammed'e 'inâyet-i kesîr idüp kudret ve 'azâmetiyle envấ1 yüz aklıklar1 verip derûn-1 cihân-1 nümâda ve kubbe-i hazrâda bu gazây-1 ekberîn hasenât ve derece-i sevâb-1 'aliyyesini ve şühedâ ve ve'l-mücâhidîn kullarına 'atâ eylediği rahmetini ve firdevs-i a'lâda verilen ni'met-i fîrâvânların ehl-i heftis-semâya münteşîr eyledi. Ve mü’min-i sâdık vahdehû lâ şerîke leh olub fî sebîlillâhî Te'âlâ canıyla başlarını fedâ eyleyen 'ibâdına derece-i 'âlîlerin cümleye 1zhâr eyledi, kürre-i zemînde memleket-i İslâmiyeve münteșîr idüp sem'-i gûșen iden mü'minîn ve'l-mü’minât ve 'ulemâ ve sulehâ cümlenin hayır duâlarına sebeb kıldı. Elhamdü lillâhi Rabbil-'âlemîn ve tershâne-î 'âmira kethüdâs1 mükerrem ve sifât-1 behrâm Seyyid Hasan, Allah zîde şecâ‘atahû fî sebîlillâhi Te‘âlâ gayret-i dîn-i Muhammed-i İslâmı bende-meyân idüp çâr-gûş̧et humbara ve semâniye firkata ile kendûsi dahî donanmış filikaya girüb cümlenin pîşterine düşûb küffâr-1 hâksârın kûhî bülend sefâyînle beğ tahtına dâhil olub belây-1 âsumânı humbaralarında endahte idüp ve karadan tophânelerden remy olunân müdâfa'alar ve tophânelerin mukâbilinde olan gûh-1 bülend-i sefâyînlerine remy olan küre-i müdâfi‘ ol sefâyînlerin vergilerin ve sertâbların ve armasin tuyûr-1 ebâbil gibi beyne's-semâi'l-'arza tayarân eyledi. Sefâyîn-i 27/ma'rûkaların yemîn ve yesârı kuş kafesi mislî olub derûnlarında mürd olan kefere-i habîslerin hesâbı hadden bîrûndur ol sefâyînler ol hâle müncer oldular ki demdân-1 minşârdan ihrâc olan muhâbele dönmüştür ve tersâne kethüdâsı tûle 'ömrehû ve zîdellâhü şânühû ol hadden küffâr-1 hâksâre humbara-i belây-1 semânîler endahte eylemişlerdir ki şihâb-1 semâ gibi küffâr-1 melậ̂inin üzerine nâzil olub ve nice küffârların 'ömrü defterin tayy eyleyûb cân kilâblanını lezâba irsâl eylemiştir. Elhamdü lillâhi 'alâ dîni'l-İslâm ve 'alâ tevfîki'l-îmân ol kimesne kendi kuvvetine i'timâd idûb bî-pâk ola, lâ-cerem bu makûle kimesne nefsini mehâlike ilkâ etmiş olur. Ol küffâr-1 hâksârın 'asâkir-i la'îni berren ve bahren taşa tutulmuş kalb-i meklûbe dönûb harman-1 'ömürleri müslihây-1 şimşîr ile rikkat olmuştur, ol melâîin-i hazelehümullâhü südde-i a'dâ heybet-i düşman ve serkeşân düşmanların necâğı re'si olan lîman burçlarına aynı 'ibret ile nazar eyleyüb gördükde heft-i ser-su'bân-1 ter gibi çeker ve üzerinde olan 'asâkir-i İslâmı gördükde küffâr-1 bî-dînin tedbîr ve fîkr-i cem‘iyyeti külliyet ile perîsân ve talân olub her bir ceyi öyle heybet ile gördû ki dehanların if'ây-1 ter gibi feth eylemişlerdir. Ol küffâr-1 hâksâr-1 şeyâtîn bu keyfiyet-i hâl ile burçları teferruc 
eyledikde kalb-i murdârlarına havf ve cemre-i cahîm nâzil olub vilâyete mukarrab olmakla cesâret ve mecâli olmadı. Endişe-i zindân-1 'ukûbette şîkeste-i hâl-i zârdır kaldı. Allâhü zîde havfehüm ve meşakkatahüm, âmîn. Ol küffâr-1 hâksârın heybet-i İslâmdan tâkati tân olûb tarîk-i bahâne fi'l-cümle mecâli kalmayûb dedi ki biz bu bend-i belâda yâbeste kalırsak hâlimiz nice olsa gerektir, deyub âh u zâr eyledi, çûn kûffâr-1 hâksâr 28/bu uslûb üzere beș buçuk sa'at cenge tevakkuf olûb ba'dehû tevakkufa mecâli kat' olub 'asâkîr-i menhûselerinden irtîkâb-1 esîrliği sem-'i gûş eyledikde bahr-i ğussâya daldı ve ğavvâs-1 'aklını 'ummân-1 fikre saldı. Ve külbe-i hüzün içinde kaldı. Elhamdü lillâhi ve'l-minne, fursat-1 intîkâm, düşman-1 dîn terk olunmayıp hil'at-i helâki düşmanın kaddine göre giderdiler 'alâ külli vechin hîle-i bed-kâr-1 a'dâdan gaflet olunmadı. Bu misillü gazâyı kîri çeşm-i felek görmemiştir, beli sâbııda çok oldu nîce halâlûş-1 ğazâ, biziz ol mûr-i zaîf ol siyah kıldır a'dâ, el-hamdü lillâhi hamden kesîrâ, bu Cezâyir kullarına vâcib oldu her du'â, serlerin Allah içün kıldılar cümle fedâ, sükkân-1 heftîs-semâi dürdi zeminde vuhûş-u buhûș tuyûr-u tayrâna teferrûc eyleyub nusret ü 'inâyet gîrd-kâra hamd ü senâ ve şükr-i bîşümâr etmişlerdir, pâdişâhım himmetinle söylenur her şânımız, bî-dîn-i düşmana yoktur hiç bizim imânımız, bi-hamdillâh 'atâ kıldı nusreti perverdigâr, tîğ-i şiddetle bozuldu dîn-i dûşman-1 hâksâr, himmet-i şehinşâh ile ve 'avn-i hüdâ ile kahr-1 felek, küffâr-1 la în-i şeyâtînin rik'a-i vücûd-1 murdârlarına bilâtahmîn gars idüp ve âb-1 şimşîr ile iskâ idüp helâk eyledi, ve şikâfil-arzda bahçe kenarlarında yebğâhûm keyfe mevtü'l-kelb ve nehr-i bilâ-feyz ve temevvüc idüp vücûd-1 murdârların gark idüp ka'rında kaldılar, Allâhü Sübhânehû ve Te'âlânın lütf u 'inâyetiyle ve hürmet-i habîbi 'ale'l-Mustafa sallallâhü Te'âlâ 'aleyhi ve sellem nusreti erzân k1lub ihsân eyledi. Ol küffâr-1 hâksâr-1 'asâkir menhûsalar1 berk-i süyûf ile mânend-i melâh-1 hıref olub lâşe-i murdârları leb-i deryâda fevkar-reml ser-nigûn olub cerdîre döndüler, Hak Sübhânehu ve Téâlâ İslâmı 'azîm ferhunde-kâl eyledi. 'Asâkîiri'l-mücâhidîn en-nusretü zâde'llâhü 29/hayrahüm. Küffâr-1 hâksâru'l-müşrikîn le'anehümüllâhü kelle-i kilâblarını bölüklerinden resk idüp gâzîlerin destanlarında ikişer üçer dâru'l-'izzette getürub kerem-i mîs-i mîrâna nâil oldular, ve kimîn-i kethüdây-1 mükerrem zâdallâhü 'ömrahû hazretlerine ve kimîn-i ağây-1 mükerrem tûle 'ömrahû hazretlerine getürub otağlarının önlerine küffârın kelle-i kilâblarını burçlar gibi binâ eylediler, sacâdetlü kethüdây-1 mükerrem ve ağây-1 mükerrem kelle getiren gâzîyâna kemâl-i 'îzzet ve 'azîm hürmetler idüp bahşişler 'atâ olunûb mesrûr-1 handân oldular. Ve kimîn-i mekremetlü tersâne kethüdâsına götürub bahşişler 'atâ idüp ferâh eylemiştir, ve hazreti Mehmed Paşa edâmellâhü 'ömrahû ve devletehû ilâ yevmi'l-kıyâm kelle getiren gâzîlere kesîr 'izzet ve rif'at ile bahşişler 'atâ ve ihsân firâvân eylemiştir. Bu kelle bahşişlerinden sâir 'asâkir zaferi'l-mücâhidîne 'alâ seviyyen kemâl-i sürûr ile bahşişler ve ikrâmlar olunmuştur. Elhamdü lillâh ve sadaka-i şehinşâhi halledallâhü hilâfetehû ilâ yevmi'd-din. Cümle 'asâkir-i nusretşiâra yedişer akçe terakkiler 'atâ ve ihsân olunmuştur, ve celb-i haberden 
mümkün olanı der̂^‘ etmediler, ve cümle ahâli vilâyet ve memleket-i mü'minîn ve'l-mü'minât ve'ş-şebbâh ve's-sıbyân ve'l-'acâyiz cümle mesrûr ve şâdân u handân olub lâ-yu'âd küsfendân-1 kurbân olub sad-hezâr şükür ile ümmet-i Muhammed 'îd-i ekber eylediler. Elhamdü lillâhi'l-meliki'l-ğaniy ve hazreti Mehmed Paşa ve dâmellâhü 'ömrahû ve devletehû bu kesîr hayır ile sa'y-i belĭği rûz-1 rûşen gibi 'âleme 1zhâr olmuştur. Ol küffâr-1 bedbaht şûm-1 cezâl-1 mel'ûn hazelehümüllâhü 'asâkîr kilâbların metrîs-i menhûselerine tedbir idüp pûşide eyledi. 'Asâkîr-i İslâmın meydân-1 mu'ârekede eyledikleri merd-i şirâneliklerini ve şecâ'at-i behrâm hareketlerin gördükde kendü 'asâkîr-i murdârlarının hâlini tefekkür idüp hemen öyle fehm eyledi ki 30/dehân-1 rûbâhdan tahlîs-i cân eylemiş mâkiyân misilli târumâr olduğunu gördükte engüşt-i küffâr-1 dendân arasında kalûb fîkr ü tedbîrin telef idüp kendi kendiye tefekkür eyledi ki bizim bu hâlimiz gâyet 'aks-i hâldir, ve bizler bend-i belâda yâbeste kaldık ve dedi ki eğer bu şeb-i belâda bu leb-i deryâda kalmak muktezây-1 'akla muhâliftir, ve mevz1-'1 mühlîkedir ve eğer hîle-i nefs göstermezsek șişe-i nâmus kadîm-i zemîn-i mezellete uravuz. Ve tâife-i Hıristiyâni Cezâyir'in pençe-i minkârından bir dürlü tarikle istihlâs-1 cân-1 necâta imkân yoktur. Ve cümle bahr-i deme gark olub helâk olmamız mukarrardır, dedi. Hemen ol küffâr hazelehümullâhü fîkr idüp dedi ki her kârın timârını muktezây-1 makâma göre itmâma yetiştirmektîr, dedi. Donanmay-1 mağrûkalarını üzerine hâkim olan cenerale der-'akab kağıd tahrîr idüp keyfiyet-i hâli ve kendilerinin giriftâr-1 teşyîl-i şîmşîr olub ankây-1 kâf1 Cezâyir'in pençe-i minkârına şîkâr olub istihlâs-1 cân olmalarından nâ-ümîd olduklarını i'lâm eyledi. Ve encâm-1 keyfîyetleri yine müncer olsa gerektir, beyân eyledi. Ve dedi ki ne bana tekellüm-i kudret müyesserdir ve ne sana ismâ‘a tâkat mutasavverdir dedi. Ol la î̀nin kânûn-1 derûnunda nâr-1 süyûf şiddet bulub dedi ki; eğer bu gece bu muhâlife leb-i deryâda sabah idersek keştî-i hayâtımız tûfân-1 bahrden gark olmak mukarrardır. Zîrâ seylâb-1 tîğ-i ğadâb ile harâb olduk, ve çerâğ-1 'ömrümüzü bâd-i helâkle söndürdük. Bir endîşe edelim ki onun sebebiyle hicrânımıza bir merhem erîse dedi. Zîrâ cümlemizin pâyi şebîke-i sayyâd-1 şimşîre dâhil olduk dedi. Ol küffâr-1 la'în bedkâr tama-'i hâmiyle ve cihet-i tâmmiyle sayd-1 Cezâyir için kemer-i kasd-1 meyânına kuşanmış iken ol Hazreti Hüdâ celle celâlühû ol küffâr-1 hâksâr1 tekebbürlügüne göre hâk-i zemîne yeksân eyledi. Elhamdü lillâhil-ğaniyyl-a lâ, $\underline{31 / o l ~ k u ̈ f f a ̂ r-1 ~ l a i ̂ ̀ n l e r i n ~}$ devha-i ömürleri reh-i kazâ ile biçilmiştir. Ol mağrûk donanmay-1 menhûslarının cenerali bu keyfiyet-i hâli sem- 'i gûş eyledikde cân-1 murdârı başına sıçrayıp 'akli şeytâniyesi zâyi' olûb hemen der-'akab sefâyinlerine haber irsâl idüp cümlenin müstedilleri cem` olûb hâzır ve müheyyâ eylediler, delîl-i zullâma muntazır oldular. Ol kâfîr-i la'în dedi ki şöyle bil ki cereyân-1 fermân-1 kazâda dânây-1 kâmil-i nâdân-1 câhil ile yeksândır emr-i kazâyı kuvvet-i bâzûrde eylemek muhaldîr, ezelde her ne yazdı dest-i takdîr, olunmaz bir nokta tağyîr olacak nesne olur dâd u bîdâd, gerek gönlünü ğamkîn tut gerek şâd, derilse bir araya cümle 'âlem, içinden idemez bir harfini kem, ve lâkin kelâm-1 tekebbür ile tevakkuf idüp huzûr-1 kralda Cezâyir benim mukâbilimde kutûr-1 sabahdır, 
deyub lâf u güzâf idenin hâli budur, tekebbürlük helâk-1 fikirdir dedi, eczây-1 endişe ve merhem-i fikir bu cerâhata aslâ fâide vermez hemen bâkî tâife-i Hiristiyâni tâife-i İslâmın pençe-i şîr-i minkârından istihlâs eylemektir deyub cümle sandallarına 'âkil adamlar koyub tavsiye eyledi ki hemen 'asâkir-i Hiristiyanları bir selâmet ile tahlîs ideler bâkî mihmandan tama' olunmaya dedi. Ol küffâr-1 bed-kâr ve bedbaht yerde olan ceneral 'asker kaputanların ve okçuların bir yere encümen idüp tenbih ve tavsiye eyledi ki bu şeb-i zullâm-i halde metrîslerinizde tevakkuf pâ-olûb zâbitâneleriniz destinizde ve destiniz âteş-i zinde olub sakınub âteş-i şedîdi terk eylemesiz. Şâyet ki İslâm 'askerî firsat bulûb gâfilen hücûm idüp metrîs-penâhlarımız lâne-i mûr gibi heder idüp cümlemizi perişân eylemek mukarrardır, dedi, ve leb-i deryâdan ka'rr-1 deryâya ilkâ ideler, deyub bu tavsiyet ile cümle 32/'asâkîr-i meş'umları metrîs menhûselerinde tevakkuf eylediler. Garb-1 şeb lîbâs-1 'Abbâsî giyub perde-i zullâmı tâk-1 sipihr minâkâm önüne çekti. Ol küffâr-1 bed-kârın zamîri buna verdiği firsat ganîmettir, neye tevakkuf etmeli, dâmen-i firsatı küşâd-1 dest eylemek külli hamâkattır, zîra bu mahal-i mevzu' te'hîr eylemek hedm ü helâke muntazır olmaktır. Zîrâ bir cümle ile nicemizi pây-1 mürdâne fîlde helâk olmuş mûr gibi helâk eylediler, ve eğer bir hamle dahî iderlerdi, cümle tâife-i mesîhânı pâymâl idûb âğuşte-i hûn u hâk olmak mukarrar idi. Nice Hıristiyânlar pây-i eşterde helâk oldular. Ve eğer bu muhâlif mevzû‘da kalıp sabah olursa yine bizler dahî cemel ile hâk-i zemîne ser-nigûn ve dem-i la'limizi eşrib etmeleri meçhûl değildir, dedi. Ve zûm-i fâsidelerine münâsib dediler ki, İslâmiyyûn tâife-i mesîhânın ve hıristiyânların hûn-1 la'llerini kendilerine istihlâl görmüşlerdir, ammâ bizim şer-'i mürûvvetimizde haramdır bizde haram olanı onlar mubah ve helâl bilmișlerdir. Pes bî-tevakkuf bu menzîl-i muhâtaradan bir sa'at mukaddem raht itmek gerektir. Ve eğer bu mevzû́' meks olunursa tekrâr tî̆g-i musîbete mübtelâ olmaktan gayri tarîk yoktur, ve bu mahalde ikâmet-i kesîr hilâfet-i muktezây-1 re'yi sâhiptir dedi, tâ 'asâkirimizi bu menzil-i muhâtara-i muhâliften bir tarîk-i hîle ile ref' idüp fetânetleri olmadan dehân-1 sübândan tahlîs-i cân idevûz, dedi. Bir kimse ki 'arza-i hâristâna uğraya ana kazâdan emân müyesser olmaya, dediler. Ol küffâr-1 bed-kârın hâli diğer güni yine müncer olduğun ve dâire-i meşakkatte zikr-i hâl olub girdâb-1 feza'a giriftâr ve re'y ve tedbirleri külli perîşân olub bahr-i medîdede gark olduğun taraf-1 İslâmın kemâli fetâneti olmadı. Anın içun ki bir düşman-1 hiyânet bir küşûr-1 gayra pâ sürse bu mezkûr mühimmât ve âlât ile 33/aslâ bir 'akıl ve fikir mutasavver eylemez ki ol 'adüvviy-i ekber dîni Muhammed nısf-1 harâb-1 memleketin ve donanma-yı mağrûkaları külli sefîneleri kûh-i bülend-i peyker-i ejder korsan dâiresinde olan müzeyyen ki sedd-i iskender gibi ve nice top ve humbaralar cümle İslâm üzerine sü‘bân misillü dehânın kûşâd eylemişken mühendis-nümâ olsa küffâr-1 hâksârın rücû-' 1 red idüp firârîn-i bahr-i endişesinde mutasavver eylemez 'asâkîr-i İslâm dahî ol melâ̂înin bu mertebe kendüye dünya zîk olduğundan fetânetleri olmayub mîr-i mükerrem Sâlih Beğ ve mîr-i mükerrem Tatra beği ve mükerrem 
halîfe-i garb ve sancak ağaları cümle sa'âdetli mekremetlü kethüdây-1 mükerrem ve mürüvvetlü ağây-1 mükerrem huzûrlarına cem' olub âdâb-1 devlet ve sa'âdeti yerine getürûb şehinşâh-1 'âlem-penâh hazretlerine du'â-i kesîr idûb ba'dehû Hazret-i Mehmed Paşa ve dâme 'ömr ü devletehû du'âlar olunub kelâm u nutuk eylediler ki bu küffâr-1 la înin bir çâre ile pây-1 menhûseleri firâr-1 cadde istikâmetine irmek ve bir hîle ile dîde-i ümidleri çehre-i murâdı görünmek muhaldîr dediler. İnşâllâhû Te âlâ ve nusret-i kibriyâ hâzelleylü küffâr-1 laîninin cânib-i sâlisîn şattul bahirden ahz idüp merbût ve müstahkem idüp tevekkeltü 'alellâh vakt-i subh u sâdıkda 'asânullâhü'l-hayr cümle 'asâkir zafer-i nusret ile ma'an 'arab ve 'aryân ve kabâil bir hamle-i 'azîm ve bir halâlûş-1 kebîr dahî idevüz ve hüve 'alâ külli şey’în kadîr bi-'avnillâhi Te'âlâ 'azze ve celle metrîs ve 'âşiyân-1 penahların 'alâ himmeti evliyâi ve's-sâlihîn ve himmet-i halîfe-i zıllullâhi halledallâhü hilâfetehû ilâ yevmi'l-kıyâmı ve'l-cevâb du'ây-1 hayırları berekâtıyla dıraht-1 vücûd-1 murdârların minşâr-1 süyûfla cümle ağsânların kat ${ }^{\varsigma}$ idüp harfünnâr idüp pây-1 rehne bîhûş idûb kemend-i şimşîr ile cerri ka'r r-1 deryây-1 'azâb olmaları innallâhe 'alâ külli şey'in kadîr 'âlem-i şehâdetten 'âlem-i ğayba 34/mertebe-i 'âlî ile gitmemize Allâhü yessir lenâ deyûb Fâtiha eylediler bu tedbîri cümle zâbitân ve ağây-1 serdengeçtiler ve ağâay-1 ve'l-kilıçlar ve 'asâkir-i nusret savâb-1 'azîm görûb cümlenin ittifâkıyla ol ma'den-i fikir ve sandûka-i 'akıl ve sâhib'r-re'y ve't-tedbîr Hazreti Mehmed Paşa devâmallâhü saltanâtehû ve nusretehû i'lâm olunûb ol evliyâ makâmı ve'l-kutubu'l-medâr bu ittifâkı makkûl görûb dest-i küşâda dergâh-1 'izzet olûb taleb-i nusret-i İslâm oldular. 'Asâkiri zaferu'l-mücâhidîn öyle 'ahd ü misâk eylediler ki sînelerimiz fî sebîlillâhi Te'âlâ sad-pâre olunca düşman-1 dinden hazelehümullâhu red çevirmek muhâldir. İnşâallâhü 'ale's-sabâhi'l-hayr mevzu-'i mu'rikeyi şa'şa-i tị̆ ile zulümât-1 pây-1 küffârdan bir nûr u ziyâ idevüz ve kaftân-1 hayâtların endâze-i şimşîr ile keyl idevüz ki seb-'i semâvâtta seyrânımız eyleyub onlar dahî bizimle tevhid idüp ümmet-i Muhammed'in nusretine du'â ideler dediler gelelim ki ol küffâr-1 la în ve tâife-i şeyâtîn hazelehümullâhü ol şeb-i zullâmda metrîs-i menhûslarından top ve zâbitâna ve sâir fennûn-nâr 'akla gelmez hadden bikıyâsın ateşler gösterdi. Bu cümle-i İslâmi'l-mücâhidîn havfiyle cân-1 murdârları ra'şaya düşüp varak-1 hazân gibi leb-i deryâda tevakkuf-pâ oldular, ve dâniş-i șerârları itfâ olmadı. Havf-1 hücûm-1 İslâmdan envâ-' ${ }^{1}$ fișenkler endâhte iderdi. Cür'a-i dest-i sitemkâr-1 felekden nûş iden dâimâ oldu, mest bu dünya bir yerdir ki nice şîr-i murdârları kemend-i mihnet-i gaflete ser-nîgûn itmişdir. Zirâ bu cerâhat mühim gaflet ile mülâyemet bulmaz deyub sefâyîn-i mağrûkelerinden ve firkatalarından öyle âteş-i nemrûdu saçtı̆̆ına âsumân anlamıştır. 'Âlem-i fenâ zulmetü'l-leyl ve sadây-1 müdâfi' ve sefâyin-i humbara belây-1 âsumânîler endahte iderdi, ol küffâr-1 tâife-i şeyâtînin la'netullâhi 'alel-müşrikîn 'asâkîr-i menhûsalarının sakf-1 dimâğgnda lezzet-i süyûfdan eser olmakla $\underline{35}$ /dâniş-i metrislerin kat' eylemeyub havflerinden mecalleri kalmayub tahlîs-i cânları içün beynlerinde 'azîm zâhir olub sadâları 'ubûka serçekti. Bizim cümlemiz kânûn-1 süyûfta püryân olduk, meâbına deyû âh u figân eylediler. Ol 'asâkir-i küffâr 
silahların remy zemîn idüp taraf-1 İslâma teveccüh eylediler ve ceneral ve okçuyalları 'asâkir-i murdârlarından bu kelâm-1 sem-'i gûş idûb bu hareket muhâlifi fehm eyledikde 'aklı başından gidub deryâda olan firkatalara işâret olunub ateşleriniz kat' olunmaya. Ve lâkin iktizâ-yı 'âlem-i zullâmü'l-leyl olmakla ve birde bu ki firkataların ve sefâyinlerin şiddet-i nârı sebebiyle 'asâkir-i küffâr-1 cesâret idüp ve selâmet bulmadılar, ve tahlîs-i cân idemediler ve birde budur ki Hazret-i Mehmed Paşa nasarahullâhü ilâ yevmi'l-inkirâzi'z-zamân emr-i celîlil'şşânları sâdır oldu ki zinhâr hengâm-1 pür-hâş̧da firûzende esîr olunmaya, hemen 'alâ kaderi't-tâka ve 'avnüllâhi Te'âlâ kelle-i kilâbların getürmek meydân-1 kârzâr1 gâhda küffâr-1 laî̀n gördüler ki gâzîlerin destine giriftâr olan hayât-1 fânîlerinden ve selâmet-i istihlâs-1 cân oldukları ecilden selâmetliklerin tasdîk edemediler. Zikr-i 'asâkir-i küffâr taraf-1 İslâmiyeye gelûb canların tahlîs ideceklerin fehm ü tasdîk ideler idi. Cânîb-i küffârda bir şahıs kalmayub taraf-1 İslâma gelirlerdi. Hayrihî ve şerrihî minallâhi Téâlâ ve eğer küffâr-1 hâksâr mü'minlerin keyfiyet-i hallerin fehm idelerdi. Kendülerine 'azîm-i selâmet olurdu ve lâkin fehmleri değildir ki kalb-i mü'minînin âteş-i hışımları âb ile itfâ olur ve sahîfe-i nâsiyesinde, li-harîsi mahrûm-1 mefhûm-1 beyandır mekri ol hınzîr-1 la'în tekebbürlük ile dâru'l-cihâd Resûlullâh sallallâhü Te'âlâ 'aleyhi ve sellem ol küffâr tahrîs olub kasd-1 ahz-1 beled eylemesi kendülerinin dem-i murdârları imiş baht-1 $\underline{36}$ /menhûs sibahları re'yi murdârlarına muvâfik gelmedi. Hak sübhânehû ve Te'âlâ kemâl-i kudretiyle küffâr-1 la'îni makhûr ve münhezim ve zelîl eyledi. Elhamdü lillâhi'l-meliki'l-mennân, el-hâsılu'l-kelâm vakt-i subh-1 sâdıkda cümle 'asâkir-i bed-kârların ol küffâr-1 laîn sandallarına dâhil idüp donanma-yı mağrûkalarına irsâl eyledi, ve nice küffâr-1 kelâm tahrîs tahlîs-i cân olub havf-1 İslâmla ta'accülen kethüdâların sandallarına ve filikalarına ilkâ edemeyub ka'r-1 deryâya gark oldular, ve teşebbüslerinde câmelerin ğarr idüp ve destlerindeki zâbitânelerin ve meyânlarında olan ispatalarını nahyi ve remy eylediler. Hemen istihlâs-1 cân deyüb dîde-i murdârları külli eşyâdan baî̀d oldu. Ve küffâr-1 hâksârın 'aynı menhûslarına candan gayri bir eşyâ zâhir oldu. Bu kadar eşyâ ve mühimmât ki yukaruda zikr olundu. Cümle sitem idüp tahlîs eylediler hamsete 'aşer müdâfi ve isneyni humbara ve âlât-1 metrîs ve çarh-1 felek ve tüfenk böyle âlâtü'l-harb becâyidi 'akıl tasavvur eylemez. Âlâtü'l-harb sellim eylemiştir, mevzu-'1 mu'rike bir misl-i bed-sitân olmuştur, ol küffâr-1 hâksârın arasına eylediği metrîs-i menhûseleri sedd-i iskenderden nişân virmiştir. Ol metrîsin taşray1 çît ve dâhilî dahî çiti ikisinin beyni kebîr torbalar mu'ammer bir-remil arasına itmişler hemen bir kal'a misâli derûn-i metrîste yetmiş zokâk isteyebilmişlerdir. Yetmiş iki hendek ve her hendekte üçer yüz ellişer kâfir dest-i humbara kândan ve topçuyândan ve sâir âlât-1 harb huddamından mühendis-i nârdan gayri ve çarh-1 felek 'akla mukarrab değildir. Ol küffâr-1 la'în hazelehümullâhü bu mezkûrların cümle fedâ ve sellim idûb istîhlâs-1 cân itmişler. Allahü zîde cezâühüm, âmîn. Vaktâ ki kelâmımız orada karâr eylediği cümle zâbitân ve 'asâkiri'l-mücâhidîn subh u sâdıka muntazırlar idi. Çûn ğurâb-1 
siyâh cenâh-1 zulmetîn 'âlem-nümâdan ref' itmeğe bed' 37/eyledikde gencûr-1 kudret-i miftâh-1 müsbitle kıfl-1 hazâne-i âfâkı feth eyledi, ve dest-i dirahşân-1 âfitâb-1 mahzen-i felekten nukûd-1 encûmi zîr-i dâmen şuâ'a saçtı. Çûn 'asâkir-i zafer ve zâbitân ve ağalar ref 'ü ser idûb leb-i deryâya nazar eylediler. Maksûd ve ma‘hûddan eser görmeyub dediler ki ey dirîğa, ol küffâr-1 hâksârın cân tuyûr-1 habisleri minkâr-1 şikârımız iken bâl-i pervâz eyledi, ve ebdân nehirlerinden âb-1 nûş idüp atşânımız teskîn olûb kalbimiz bârid oldu, ve dediler ki dirî̆ğ-i bu sûr-i ma'nâya aldandık, ve hayf bu hevây-1 hayâl ile sayd-1 helâlimiz elden çıkardık dediler. Kimin 'akl-1 kâmil ve temyizi şâmil ola, pâye-i sâfilde kalmaz, derece-i 'ulyâya vâsil olur, ve kimin 'aklı za'îf ve re'yi nahîf ola mertebe-i şerîfden menzili tedennî ve tedennî k1lur dediler ol küffâr-1 hâksâr-1 keştî-i vücûdları bahr-i şimşir-i zehre müstağrak iken müsâdif hâliyle tahlîs-i cân eylediler, ammâ şol kimse ki câm-1 gayret-i İslâmı nûş idüp kendü varlığın ferâmuş eyleye, iksir-i ekber ve kibrit-i ahmardan sad mertebe evlâdır ve şişe-i firsatı seng-i gaflet ile şikest eyledik dediler, ki her emîrde kâtib-i kudretten dîvânhâne-i ezelde ceffelkalem vâki' olmuş ola lâ-büddür ki 'arsa-i 'ademden muttasıfa vücûda gele, lâcerem andan ihtirâz ne fâide verir, çûn fezâ levhine çekildi kalem, bize yazdı nice mîr-i 'alemgâh, olur ki havâdis-i takdîr, ser ü azâd iken urur zincir, bizim dahî bu gîce pâyimize kudret ile gaflet zincîrîn urdular, 'asâkir-i zafer-i nusret gâyet ile şeyhûne ikdâm eylediler. Ve lâkin takdir-i Hüdâ ve kalem-i kudret-i ezeliye levh-i pîşânelerine helâkların tahrîr itmemiş̧îr, ne kadar cehd eylesek bir murâda, olmaz mukarrarden ziyâde, nûş iden şerbet-i tị̂̆i belâsın virân olur. 38/Söylenür tâ haşra dek dillerde destân olur. Ol küffâr-1 hâksârnn cem‘iyyeti sâika-i şimşîr ile hûn olundu, rub-' 1 meskûrda dillerde destân oldu. Tâife-i efrenc bu bâbda nice kitaplar îcâd idûb sâdır olan halâlûș meddahları dillerinde cemi' tâifeler sem-'i gûş eylediler, ol küffâr-1 melầî̀nin böyle böyle hîle-i sâkıt ile pençe-i minkâr-1 'ankâmızdan ihrâç olûb karârîn-i fîrâra tebdîl eyledi böyle istihlâs-1 cân ideceğîn aslâ fîkr ü endîşemize mukarrab olmad1, 'asâkîr-i İslâm 'arab ve 'aryân metrîs-i menhûselerine dâhil olûb gördûler ki cümle âlât-1 harblerin ve topların ve tüfenklerin ve câmelerin selm idüp hemen yek canların istihlâs eylemişler 'arab ve 'aryân ve kabâil eşyâların ganîmet idüp yağma ve gâret eylediler. Ve sandûk ile 'asâkîr-i murdârlarının mûciblerin dahî selm eylemişlerdir. Ümmet-i Muhammed 'azîm ü şâd u handân olmușlardır. Elhamdü lillâhi hamden kesîr. Ve ol küffâr-1 hâksâr tahlîs-i cân idüp sefinelerine vâs1l olduklarında sefâyinlerde olan küffâr-1 şeyâtînler taşradan bozguna gelen küffârlara selm idüp mügâyir kelâmlar söylediler, dediler ki; müslümanlar sizi kemend-i süyûfla harkûş gibi sayd eylediler ve şîr gibi hûn-i laclinizi nûş eylediler, ve huruşti peştinize rekb idüp kellelerinizi kat' eylediler. Ve taşradan gelenler dediler ki, bizim keyfiyet-i hâlimiz ol sayyâda döndû ki kâd u vahşi sevdâsina dâm-1 dûzâhlar pîrâste idûb cevânîb-i erba'aya hatve-endâz ider iken bir pelenge mülâkî olub pence-i dâm işkencesine giriftâr olub girdâb-1 belây-1 yelkende cây-1 selâmet tahlîs bulmayûb helâk oldu. Amma bizler pençe-i şîrden istihlâs-1 cân eyledik. Ve eğer siz bizim gördüğûmüzü göreydiniz boynunuza 
kemend-i şimşîr dâhil olaydı ol vakit fehm eyler idiniz bizler ne siyâset-i 39/izbâr-1 süyûftan tahlîs-i cân eyledik, ve bizim başımıza nâzil olan sâika-i şimşîr-i bend-i feyza sizlere müyesser olaydı kuds-i halil olsa ol mevzı' in tavâfına pâ-sürmezdiniz ve 'ankây-1 siyâset üzerimize bâl âçub sâyebân oldu. Üzerimize nâzil olan seng-i belâya tahammül itmez idiniz, dediler, ve hâr-1 süyûf, şeb-i siyah gibi etrâfımızı havl idûb dâire-i musîbette berîha gibi feryâd u nâlemiz 'ayyûka erişti. Dediler ve tâife-i kabâil küffâr-1 hâksârın kelle-i kilâblarını süngü uçlarına reșîk idûb Allâhû Te'âlânın 'avn ü 'inâyetiyle kûh-1 sahrâlarda küffâr-1 mâl-i 'aynin rûy-i nuhûset-murdârların görmeyen mü'minîn ve'l-mü'minât teferruc idüp Allâhû Téâlâ hazretlerinin ümmet-i Muhammed'e i'tâ eylediği nusret ve lütf u 'inâyet ve ihsânet ve ni'met-i firâvânına hamd ü şükürler idüp re'slerîn 'uryân idüp secde-i şükrânder eylediler. Elhamdü lillâhi 'alâ dîni'l-islâm ve 'alâ tevfíki'l-1̂mân deyûb ferahlar hâsıl eylediler. Ve yine Resûlullah Sallallâhü Te'âlâ 'aleyhi ve sellem ve makâm-1 evliyâ ve's-sâlihîn dâru'l-cihâd Cezâyir'e devâm-1 devlete bed fa'alle kast idenleri Hak Sübhânehû ve Te'âlâ bunlardan beter idüp makhûr ve münhezim eyleye ve cem înlerin tâlân eyleye âmîn, deyûb teveccüh-i dergâh-1 'izzet olub hamd ü senâlar eylediler. Allâhü tekabbel du'âehüm âmîn. Dâima sayyâdi's-süyûf ve cellâd u felek düşman-1 dîni kahr eyleye, hürmet-i ism-i kahhâr dediler ve giryâbların pençe-i şimşîrden halâs eylemeye, âmîn. Hak Sübhânehû bu gazâyı ve bu halâluş-1 ekberi şehînşâh-1 'âlem-penâh halledallâhü hilâfetehû ilâ inkirâzi'z-zamân ve ilâ yevmi'l-kiyâm hazretlerinin devlet ve saltanat-1 eyyâm-1 sa'âdetlerinde himmet-i 'âlîleriyle kabûl eyleye, âmîn. Ol küffâr-1 laînin 'asâkîr-i șeyâtînleri bu halâlûş-1 mu'ârekede tîğ-1 hâffi ile ve serb-i zâbitâne-i gâziyân ile 40/dört bin kâfir şimşîr-güzâr olub cân-1 habisleri fi'n-nâri oldular ve yirmi sekiz okçubâl mürd olmuştur. Yüz doksan bir okçubâl zahmedâr olûb nısf-1 cân ile sefâyin-i mağrûkalarına ref eylediler, ve zahmedâr 'asâkir-i birler becâb-1 evvel dâme siyaset ve serb-i zâbitân gâziyân ile helâk olûb ecsâm-1 murdârlar1 ta'âm-1 mûs u mâr-1 tuyûr-1 vuhûş ve ğurâb ve şuâl ve rubâh oldular. Elhamdü lillâhi ve'l-minne, ve sedd-i İskender gibi olan metrîsin şebânların süht eyleyûb hâkesterîn bâd-1 nümâya virûb lücce-i 'ummâna verdiler. Elhamdü lillâhi Teâlâ eyyâm-1 devlet-i şehînşâhîde böyle yüz aklıkları olmuştur. Himmet-i zıllullâhi halîfetü'l-'arz hazretlerinin du'âları berekâtiyle böyle tekebbür ve mağrûr küffâr-1 hâksârı yeksân u zelîl ve bed-nân eyledi. Hak sübhânehû 'azze ve celle ol hinzıra envâ-'1 meşakkat 'atâ eyledi. 'Arza-i Cezâyir'in sevâhil-i bahrînde semen-i nüfûstan içeru eyyâm-1 nâbistanda harr-i âfitâb ve havây-i sakîl ile küffâr-1 hâksâre muhâl-i kudretiyle dâne-i 'ömürleri iltâhûn-1 felek seng şiddetînde olûb helâk oldular, ve niceleri dahî meydân-1 mu'ârekede tîğ-i İslâmdan huşiş-i rikkat ve orduları meğâlık olup helâk olmuşlardır. Ve eğer ol küffâr-1 hâksârı zinde-esîr eylemek emr-i sa'âdet ve müserrah olaydı becâb-1 esîr olurdu. Bu nusret kudret-i ilâhiyeye sad-hezâr hamdü senâ ve şükür olsun, ki ol gâlib tekebbür düşmanı kemâl-i kudretiyle şikest idüp târ u tâlân idüp makhûr ve münhezim eyledi, ve ümmet-i 
Muhammed'i şarken ve garben cihan nümâda ferhunde-kâl eyledi Elhamdü lillâhil-meliki'l-ğanîyi bekâ 'âlem-i fânîde sad-hezâr sâl-i 'ömr-i vefâ eylese. Allâhü Te'âlânın 'ibâd-1 müslimîne 'atâ eylediği nîmet ve nusret ve lütfun zerresinin hamd ü şükrün itmeğe kudret ve liyâkat olmaya öyle bir $\underline{41 / s i f a ̂ t-1}$ iblîs-i mel'ûnu pençe-i minkâr-1 Cezâyir'e giriftâr idüp taht-1 şimşîinnde zebûn eyleyûb yedi kral içinde zelîl ve rüsvây eyledi. Elhamdü lillâhi 'alâ ni'metihi, bu feth-i fütuhâttan, şühedâdan ve gâzîlerin eylediği gazâlarının hasenâtından Hak sübhânehû ve 'amme nevâlehû velâ ilâhe gayrahû cümlemizi ve cümle sâmi'ûnları hissedâr eyleye, âmîn, ve meydân-1 mu'ârekede nevverallâhü merkadehûm ve tenfe'ahû beynenâ yevmîl-ferâğ yüz yirmi kimse câm-1 şehâdetini nûş eyleyub dest-i hûrînden hidâiye-i nâime nâil olub derece-i fîrdevs-i a'lâya erdiler. Allâhümme yessîr lenâ hâzed-dereceti âmîn, ve iki yüz seksen mecârih olmuşlardır, ol küffâr-1 la î̀n dediler ki meyânımızda bir vahşet-i ğayyârin ve bir hasret-i cûybârîn kopardık ki hezâr-kurunda bu gamın def'i müyesser olmasa gerektir. Bizler bilâd-i İspanya'ya vusûlümüzde ba'z1 evlâdîn suâl eyler ve ba'z1 'iyâlîn suâl eyler ba'zı karındaşın suâl eyler bir 'azîm ğaryû ve girye ve fiğân olsa gerektir. Bu yüz karalıklar1 ile kral bizim devha-i ‘ömrümüzü mihnet-ârâ-i cefâ ile kesse gerektir. Ol küffâr-1 melấ̂̂̀n varta-i siyâset-i süyûftan istihlâs olduktan sonra selâset-i eyyâm donanmây-1 mağrûkaların lengerlerin kal ve ref idüp bâd-bânların küşâd idüp şâhin minkârından halâs olmuş bozgun külüng alayı gibi her biri bir cânibe finnâr sefer oldular. Bu gazây-1 ekberin beyânında ve kemâl-i takrîrine kudret-zebân 'âcizdir, ve hayrândır. Min evvel ilâ âhir keyfiyetini 'akl u fîkr ile cem' idüp takrîrine mümkün yoktur. İllâ hakîr muğrigiz-zünûb muhtâc-1 Fâtiha şemsi 'ayn-1 gaflet ile nazar eylediğimiz ve efrenc vilâyetlerinden gelen kağıdların sem-'i gûș idüp mefhûm-1 kelâmları fehm olunub bâ‘dehû bu fütuhât-1 celîleyi takrihe kudret olunmuştur. Cüyûş-i dîn-i mübîne bâ'is gayret-i gazâ ve mûcib-i sebeb-i du'ây-1 hayr-i müslimîn ola. 42/Şevketlü, kudretlü, mehâbetlü sultânu'l-İslâm halîfetullâhi 'ale'l-kıyâm. Muhriz-i mâliki'd-dünya mazhar-1 kelimetullâhi'l-'ulyâ hâfız-1 sünûru'l-müslimîn zâbiti umûru'l-meliki ve'd-dîn. Mâliki serîri'l-hilâfeti fi'l-âfâk1, el-âlemü bi'listihkâkı'l-fâyizu envâr-1 merhamet ilâ tabakâti'l-mihveri el-lâyicü âsâr-1 mekremet 'alâ safahâti'd-dühûr sultânu'l-hâfizîn halledallâhü hilâfetehû ilâ yevmi'l-kıyâm ve'l-mîzân hazretlerinin sem-'i gûşları olub dûri-i 'izâmlarının ve 'ulemâ ve sulehâlarının sem-'i gûșları olub düstûr-1 mükerrem ve nizâm-1 'ibâdullâh-1 memleket vâlî-i Cezâyir Gâzi Mehmed Paşa kulların du'ây-1 hayr-1 şehînşâhîlerinden ferâmûş buyurmayub hüsn-i nazar-1 gâyet firâvânların deriğ buyurmamalarına sebeb târîh-i tahrîrine cesâret olunmuştur. Bu nâme-i ferhunde ağâzz u huceste encâm-1 şemsi Mustafa Hocadır ki cümleden da'avât-1 hayriyye temennî ve nîyâz ider tekabbelallâhü Te'âlâ. temme’t-tahrîr. 273 


\section{KAYNAKÇA}

İhsanoğlu, Ekmeleddin -Ramazan Şeşen. Osmanl Askerlik Literatürü Taribi, c. III, Editiör: Ekmeleddin İhsanoğlu, IRCICA, İstanbul, 2004.

Yazıc1, Nurcan. "Osmanlı Devleti’nde Tersane-i Amire Mimarlı̆̆1 ve Mimarları" Editör: Özlem Kumrular, Türkler ve Deniz, Kitap Yayınevi, İstanbul, 2007.

İlter, Aziz Semih. Şimâli Afrikada Türkler, c. I-II, Vakit Yay., İstanbul, 1937.

Erdoğru, Mehmet Akif. "XVIII. Yüzyıl Sonlarında Cezâyir'de Türk-İspanyol İlişkileri Bakımından Önemli Bir Türkçe El Yazması: Tarih Al-Mübarek veya Tibr Al-Masbûk Fi Beyânı Cihâd-1 Gâziyân-1 Cezâyir ve Al-Mülûk", 38. ICANAS (Uluslararası Asya ve Kuzey Afrika Çalışmaları Kongresi), Ankara, 2007.

Maksudoğlu, Mehmet. "Dayı”, DIA c. IX, İstanbul 1994, ss. 59-60.

Carım, Fuad. Cezâyyir'de Türkler, Sanat Basımevi, İstanbul, 1962. 